SUSÁNSZKY PÁL ${ }^{1}$ - SZABÓ ANDREA ${ }^{1,2}-$ OROSS DÁNIEL ${ }^{1}$

\title{
A DEMOKRÁCIÁVAL VALÓ ELÉGEDETTSÉG ÉS A DEMOKRÁCIA ÉRTELMEZÉSE MAGYARORSZÁGON
}

https://doi.org/10.18030/socio.hu.2021.2.30

\section{ABSZTRAKT}

A tanulmány célja egyfelől a politikai attitűdök vizsgálatakor a Részvétel, képviselet, pártosság (NKFI119603) kutatás adatain keresztül a demokráciára vonatkozó asszociációk elemzése, a fogalom hazai értelmezése mögötti összefüggések vizsgálata, valamint a politikai meggyőződésből, a gazdasági teljesítmény értékeléséből, illetve a demográfiai különbségekből adódó eltérések feltárása. Másfelől, bemutatjuk a demokráciával való elégedettség, és a pártos polarizáció időbeli változását Európában, felhasználva az European Social Survey (ESS) adatait. Eredményeink, a pártos polarizációs elméleteknek megfelelően igazolják, hogy a demokráciával való elégedettség politikai preferencia függvénye is: a kormánypárti szavazók jóval elégedettebbek a demokráciával, mint az ellenzékiek. Ez a különbség a vizsgált európai országok körében Magyarországon kiemelkedően nagy, ráadásul az elmúlt években folyamatosan növekszik is. Azonban nemcsak a demokráciával való elégedettség esetén, hanem a demokrácia értelmezése vonatkozásában is érvényesül a pártosság. A kormánypárti szavazók más szavakkal, szókapcsolatokkal írták le a demokráciát, mint a 2018 nyarán erősen kiábrándultnak tűnő ellenzéki szavazók.

Kulcsszavak: demokrácia, demokráciával való elégedettség, demokrácia értelmezése, ESS

\section{SATISFACTION WITH DEMOCRACY AND INTERPRETATION OF DEMOCRACY IN HUNGARY}

\section{ABSTRACT}

The aim of the study is to investigate Hungarian citizens' associations with democracy through the data of the Participation, Representation, Partisanship (NKFI-119603) research. Beyond examining Hungarian citizens' interpretation of the concept the paper also explores correlations to political beliefs, economic performance and demographic differences. We also present the change in satisfaction with democracy and partisan polarization over time in Europe, using data from the European Social Survey (ESS). Our results, in line with party polarization theories, prove that satisfaction with democracy is related to political preferences: pro-government voters are far more satisfied with democracy than opposition voters. Among the examined European countries, the difference is outstandingly large in Hungary, moreover, it has been growing steadily in recent years. However, partisanship prevails not only in terms of satisfaction with democracy, but also regarding the interpretation of democracy. Pro-government voters described democracy in different words than opposition voters, who came across as very disappointed in 2018.

Keywords: democracy, satisfaction with democracy, interpretation of democracy, ESS

1 Társadalomtudományi Kutatóközpont, Politikatudományi Intézet

2 ELTE ÁJK Politikatudományi Intézet 
SUSÁNSZKY PÁL - SZABÓ ANDREA - OROSS DÁNIEL

\section{A DEMOKRÁCIÁVAL VALÓ ELÉGEDETTSÉG ÉS A DEMOKRÁCIA ÉRTELMEZÉSE MAGYARORSZÁGON}

\section{BEVEzetÉs}

A demokráciával való elégedettség, az állampolgárok demokráciáról való vélekedésének vizsgálata a jelenkori politikai szociológia és politikatudomány egyik legkutatottabb témája. Ennek megfelelően a European Social Survey (ESS) kutatássorozatban is jelentős hangsúlyt kapnak a demokráciával kapcsolatos kérdések és kérdésblokkok. Nem könnyű tehát ehhez a gyorsan változó és egyre komplexebb elemzésekkel operáló diskurzushoz hozzászólni.

Az elmúlt években azonban elkezdődött egy másfajta kutatási irány is, aminek fókuszában a nem-demokratikus rendszerek azonosítása, jellemzése és tipizálása áll. A magyar politikai rendszert az elmúlt öt évben jellemezték illiberális demokráciaként (Buzogány 2017), hibrid rezsimként (Böcskei-Szabó 2019), kívülről korlátozott hibrid rezsimként (Bozóki-Hegedűs 2017), esetleg tökéletlen demokráciaként (Bogaards 2018). A politikatudományi irodalomban a különböző szempontú elemzések szerzői egyetértenek abban, hogy a Magyarországon kialakult politikai rendszer jelentős és fontos pontokon tér el a demokrácia általánosan bevett értelmezésétől és követelményeitől.

Ezzel a kérdéssel a nemzetközi szakirodalom figyelembevétele mellett magyarországi kutatóként is foglalkoznunk kell. A fenti hivatkozások szerint a demokratikus berendezkedés változása a politikai rendszer szintjén zajlott, de kérdés, hogy ezzel párhuzamosan változott-e az emberek demokráciáról alkotott vélekedése. Elégedettek-e Magyarországon az állampolgárok a demokrácia múködésével, és változott-e az elégedettségük mértéke az elmúlt években? Mit gondolnak az emberek a demokráciáról, a demokrácia leírására milyen fogalmakat használnak? Tanulmányunkban ezekre a kérdésekre keressük a választ.

A demokráciával való elégedettség felfogható egyfajta lakmuszpapírként, ami megmutatja a társadalmi közhangulatot, a politikai közérzetet, azt, hogy összességében hogyan érzik magukat az emberek az adott politikai környezetben. Úgy véljük, a nemzetközi szakirodalommal összhangban, érdemes különbséget tenni a „megvalósult” és az „ideális” demokrácia fogalma között (pl. Kriesi et al. 2016). A megvalósult demokrácia megmutatja, hogy pillanatnyilag milyen a társadalom demokráciaérzékelése, míg az ideáltipikus demokráciafelfogás azt jelzi, hogy milyen lenne, milyennek kellene lennie egy elképzelt, jól múködő demokráciának.

Írásunk első részében a demokráciával való elégedettséggel és a pártos polarizáltsággal foglalkozó elméleteket foglaljuk össze. Ezt követően az ESS kutatások adataira támaszkodva bemutatjuk, hogy a demokráciával való elégedettség tekintetében milyen különbségek vannak az európai országok között, továbbá, hogy az elégedettség szintje és polarizáltsága hogyan alakult 2002 és 2018 között Európában.

Végül egy hazai lakossági kérdőíves vizsgálat adatait elemezve feltérképezzüka demokráciával kapcsolatos asszociációk mintázatát. Ezekre a mintázatokra úgy tekintünk, mint a demokrácia lehetséges értelmezéseire. Vizsgáljuk, hogy ezek az asszociációk és értelmezések hogyan függnek össze a válaszadók társadalmi hátterével és politikai preferenciáival, valamint a demokráciával való elégedettséggel. 


\section{A DEMOKRÁCIÁVAL VALÓ ELÉGEDETTSÉG, A PÁRTOS POLARIZÁCIÓ ÉS A DEMOKRÁCIA JELENTÉSE}

A demokrácia megítélése, a demokráciával való elégedettség mérése és az arra ható tényezők vizsgálata a nemzetközi társadalomtudományi kutatások egyik kiemelt területe. Ezért tanulmányunkban elsőként a demokráciával való elégedettség európai trendjeit mutatjuk be. Abból kiindulva, hogy az alacsony szintű állampolgári támogatás veszélyt jelent a demokratikus rendszerre (Lipset 1959, Powell 1982), az irodalomban megfogalmazott egyik alapfeltevés szerint a demokráciák nagyobb valószínúséggel maradnak fenn, vagy múködnek jól, ha az állampolgárok pozitív véleménnyel vannak a demokrácia múködéséről. A demokratikus rendszerekben a demokratikus kormányzás támogatásának kérdése gyakorlati és napi szintű jelentőséggel bír a politikai intézmények fennmaradása szempontjából (Mishler-Rose 1997).

Fontos a téma kapcsán megkülönböztetni a demokráciával való elégedettséget és a legitimitás mértékét (Gunther-Montero 2004). A legitimitás „az a meggyőződés, hogy a hiányosságok és kudarcok ellenére a politikai intézmények jobbak, mint bármelyik más lehetséges intézményi megoldás" (Linz 1988:65). Ezzel szemben az elégedettség (Easton 1965:406) a politikai vezetők napi megnyilvánulásainak és a kormányzati intézmények múködésének megítélését jelenti (Kornberg-Clarke 1992:20).

A demokráciával való elégedettség vizsgálatakor tanulmányunkban kiemelt figyelmet szentelünk a pártválasztás szerepének. A demokráciával való elégedettséget illetően a győztes vagy vesztes jelölt, illetve párt támogatásából fakadóan az állampolgárok között létrejövő „győztes-vesztes szakadék” (Anderson et al. 2005) különböző aspektusainak feltárására számos empirikus kutatás vállalkozott (lásd még: Berggren et al. 2004, Bernauer-Vatter 2012, Curini et al. 2012). Bár a győztes-vesztes szakadék a legtöbb demokráciában jelen van, egyes országokban a vesztesek elégedettebbek, mint másokban. Dahlberg és Linde (2016) eredményei alapján az intézmények teljesítménye fontosabb, mint az intézményi megállapodások típusa, amikor a nyertesvesztes különbség nagyságáról van szó. Az európai demokráciákat ESS adatokon vizsgálva arra jutottak, hogy a választások győztesei és vesztesei közötti különbséget jelentősen csökkenti a jól múködő demokrácia, vagyis a rendszer input oldalán a jogállamiság és/vagy a választási eljárások és a kormányzati múködés magas minősége az output oldalon. A makroszintű vizsgálatok arra is rámutattak, hogy a pártos polarizáció a többségi rendszerekben magasabb, mint az arányos választási rendszerekben (Lijphart 1999). Az egyéni szintű változókat tekintve Merkley és munkatársai (2019) azt találták, hogy az állampolgárok értékelik, ha a véleményüket képviselve érzik, ezért a vélemények változatosabb kifejezésére lehetőséget adó politikai intézmények és pártrendszerek tompithatják a választások elvesztéséből fakadó elégedetlenség mértékét.

A magyarországi kutatások közül témánk szempontjából fontos Huszár és Berger (2020) vizsgálata, akik a magyarországi rendszerváltást követően formálódó új középosztály demokratikus politikai rendszer iránti elköteleződésének vizsgálatakor azt találták, hogy az sokkal inkább a jelenlegi társadalmi rend támaszaként írható le, mint a polgári demokratikus fejlődés garanciájaként. A magyar esetre vonatkozóan, a pártosság fogalmi megközelítésére alapozva, Patkós (2017:44) ESS adatok alapján kimutatta, hogy a politikai táborok elfogultsága egyfelől politikai értelemben káros - például mert a különböző táborokhoz tartozó választók gondolkodásában, politikai tényérzékelésben és a politikai véleményalkotás terén is jelentős különbséget hoz létre, rontva a véleménynyilvánítás minőségét -, másfelől összefüggésbe hozható a gyengébb gazdasági eredményekkel is. Enyedi (2016) szerint a magyar eset arra világít rá, hogy ha egy pártrendszert populista stratégiát folytató pártok uralnak, akkor mind a pártok egymás közötti kapcsolatára, mind a pártrendszer környezetére (így az állampolgárok demokráciáhozvaló viszonyára) negatív hatást gyakorol. 
Az ESS kutatássorozat minden hulláma több témát felölelő blokkokból áll össze. Ebből adódóan a demokrácia értelmezésére és a demokráciához való viszonyulások több dimenzió szerinti vizsgálatára csak ritkán kerülhet sor (például 6. és 10. hullám). A demokráciával való elégedettségről a kutatók azonban minden hullámban feltettek egy kérdést: „Mindent összevetve mennyire elégedett Magyarországon a demokrácia müködésével?". Egyáltalán nem egyértelmű azonban, hogy a demokráciával való elégedettséget mérő kérdést hogyan értelmezzük. Vajon mire válaszolnak a kérdőív kitöltői, amikor ezt a kérdést látják? Linde és Ekman (2003) álláspontja szerint a kérdés a rendszer értékeléséről szól, azonban összekeverednek a politikai rendszer alapelveinek és teljesítményének szempontjai. A rendszer alapelveiről, alapértékeiről és azok működéséről szóló szempont lehet például, hogy mit gondolnak az állampolgárok, mennyire fontos alapérték a szólásszabadság és mennyire valósul meg jelenleg, egy adott ország adott politikai rendszerében. A rendszerhez való viszonyulás másik értelmezése szerin viszont a kérdés a rendszer által biztosított szolgáltatások és közjavak, valamint a gazdasági teljesítmény értékeléséről szól. Tehát, amikor az emberek a demokráciával való elégedettségről feltett kérdésre válaszolnak, akkor valójában a rendszer teljesítményét értékelik.

Az ESS kutatási projekt azonban lehetőséget biztosított a kutatók számára, hogy a "megvalósult" és az „ideális” demokrácia fogalmait elkülönítve vizsgálják. A 2012-es hullám tartalmazott egy kérdésblokkot, amelyben a válaszadóknak két kérdésre is kellett válaszolniuk: arra, hogy mennyire tartanak egy demokratikus alapértéket fontosnak (pl. szólásszabadság, választások tisztasága), másfelől arra, hogyan látják, ez az alapérték mennyire valósul meg a saját országukban. A két kérdésre adott válaszok különbségét a demokratikus rendszer egyes alapelemeivel való elégedettségként értelmezhetjük (Messing et al. 2013, Susánszky-Tóth 2018). Heyne (2019) rámutatott arra, hogy a demokráciával való elégedettség összefügg a demokratikus alapelvekkel való elégedettséggel. Kutatásának eredményei alapján tehát úgy tűnik, árnyalni tudjuk Linde és Ekman (2003) értelmezését, vagyis azt, hogy a demokráciával való elégedetlenség egyértelmúen a politikai rendszer (gazdasági) teljesítményéről szólna. Ha a kétféleképpen mért elégedettség erősen összefügg, akkor azt mondhatjuk, hogy a demokráciával való elégedettségről feltett kérdés részben tartalmazza a demokrácia alapértékeinek megvalósulásával való elégedettséget is.

A cikkünkben vizsgált második téma a demokrácia tartalmához kapcsolódó értelmezések. Kulcskérdés ugyanis az állampolgárok demokráciával való elégedettségének mérésekor az állampolgárok demokráciafelfogásának vizsgálata. A demokrácia összetett és sokdimenziós jelentéséhez tudományos és politikai fejlődés eredményeként számos eltérő felfogás társult, ideértve a szabadság, az egyenlőség, a részvétel, a viták, a képviselet és az állampolgári jogok védelmének eszméit, amelyek máig fontos elemei a demokráciáról szóló diskurzusnak (pl. Tilly 2007). Az állampolgárok demokráciáról alkotott felfogása azonban országonként eltérhet, és mára számos összehasonlító kutatás ad képet a demokrácia összetett és sokoldalú megértéséről (Dalton et al. 2007; Schedler-Sarsfield 2007; Shin 1999). A demokrácia sokoldalú értelmezésének feltárása segít jobban megérteni azokat a tényezőket, amelyek befolyásolják, hogyan viszonyulnak az állampolgárok a politikai ügyekhez és milyen politikai viselkedésformákat választanak (Canache 2012:5, Pickel et al. 2016:2). A demokrácia egy ilyen elvek mentén kidolgozott, ideális koncepciója globális érvényességú, vagyis egyfelől mentes a nyugati fejlett demokráciák normatív elfogultságától, másfelől elég rugalmas ahhoz, hogy tükrözze a nyugati demokratikus társadalmak újításait (Osterberg-Kaufmann et al. 2020).

Magyarországon Hunyady György és munkatársai (2015:286) egy 27 állítást tartalmazó lista alapján, szisztematikusan és mélyrehatóan vizsgálták a demokrácia értelmezését. A 27 tétel 9 tárgykör köré csoportosult: a) többség uralma; b) a kormányváltás lehetősége választások révén; c) az egyén szabad tevékenységének szükségessége és védelme; d) a jogállamiság kötelmei; e) a hatalmat összpontosító erős kormányzat; f) az 
állami gondoskodás és újraelosztás; g) a tömegek inkompetenciája; h) a társadalmi különbségek fenntartása és erősítése, valamint i) a társadalmi egyenlőség igénye, az egyenlőtlenségek csökkentése. A kutatók szerint a legnagyobb összeálló index a „demokráciába vetett hit”, majd ezt követi a „kormányzati hatalomkoncentráció”, végül pedig a harmadik a „társadalmi megkülönböztetés”. Hunyady úgy véli, hogy kutatásuk „pozitív tanulsága", hogy a köztudatban létezik a demokráciába vetett hit, amely a demokratikus jogállamiságban, az egyenlőségben, valamint a demokrácia buktatóinak, határainak elfogadásában mutatkozik meg komplex rendszerként (Hunyady 2015:303).

Tanulmányunkban a továbbiakban megvizsgáljuk, hogy milyen viszony áll fenn Magyarországon a demokráciával való elégedettség és a demokrácia értelmezése között. A fentiek alapján egyrészt azt feltételezzük, hogy a demokráciával való elégedettség és a gazdasági helyzet megítélése között szoros összefüggés mutatkozik. Másrészt, jelentős különbséget feltételezünk mind a demokráciával való elégedettség, mind a demokrácia értelmezésében a kormánypárti és az ellenzéki szavazók között.

\section{ADATOK ÉS MÓDSZERTAN}

Tanulmányunkban döntően két adatfelvétel adatait használjuk. Először a European Social Surveyt (ESS), amely 2002 óta kétévente összehasonlító nemzetközi adatokkal szolgál az európai társadalmak demográfiai, társadalmi állapotáról, a lakosság politikai és közéleti preferenciáinak alakulásáról, valamint a társadalmi attitûdök, illetve a cselekvéseket befolyásoló értékek változásairól. Ez idáig Magyarországon az ESS kilenc hulláma készült el, amelyet kezdetben a Gallup Magyarország Kft., majd a Tárki Zrt. vett fel, minden esetben személyes kérdezéssel. ${ }^{3}$ A megkérdezettek száma hullámonként 1500-2000 fő volt, amely a 15 éven felüli népességet reprezentálta. Az utolsó, 2018 őszén készült adatfelvétel során Magyarországon 1619 főt kérdeztek meg.

A cikk második részében pedig az MTA TK PTI Választáskutatási panel 3. (MTA TK PTI VKP 03) hullámának adatait elemezzük. Az NKFIH-projekt kutatócsoportjának megbízásából 2018 májusában és júniusában a Závecz Research egy 1100 fős, ${ }^{4}$ a magyar felnőtt népességre nem, korcsoport, településtípus és régió alapján reprezentatív személyes adatfelvételt készített, amelyre több, a demokráciával kapcsolatos kérdés is felkerült.

Fontosnak tartjuk jelezni, hogy a két általunk használt adatbázis 2018-ban, illetve 2019 elején, a harmadik kétharmados Fidesz-KDNP-győzelmet hozó választást követően készült. Miután választási évekről beszélünk, ezért ennek lehetnek torzító hatásai a kapott eredményekre. Róbert és munkatársai (2017) úgy vélik, hogy azokban az években, amikor az adatfelvétel és az országgyúlési (és ezzel párhuzamosan 2014-ig az önkormányzati) választások nagyon közel vannak egymáshoz, annak érdemi, adott esetben erősen pozitív hatása lehet a politikával, a bizalommal és a demokráciával kapcsolatos kérdések megválaszolására (Róbert et al. 2017:127-128).

A demokráciával való elégedettséget mindkét kutatásban (az ESS-ben és a Választáskutatási Panelben egyaránt) egy 0-10 fokozatú, nonverbális skálán mérték, ahol a 0 azt jelentette, hogy „rendkívül elégedetlen”, a 10 pedig „teljesen elégedett”, a többi skálaérték nincs megnevezve. A skála közepe az 5-ös érték. Az annál magasabb értékek az elégedettséget, az alacsonyabbak pedig az elégedetlenséget fejezik ki. A pontos kérdésfeltevés így szólt: „Mindent összevetve mennyire elégedett Magyarországon a demokrácia müködésével?”

3 Az egyes kutatások módszertanáról részletesen lásd: http://ess.tk.mta.hu/modszertan/.

4 Az adatfelvétel az NKFIH-119603 Részvétel, képviselet, pártosság projekt keretében készült. Kutatásvezető: Szabó Andrea. 


\section{1. ábra.}

A demokráciával való elégedettség átlagai és a standard hibái 95\%-os konfidenciaintervallumai, 2018

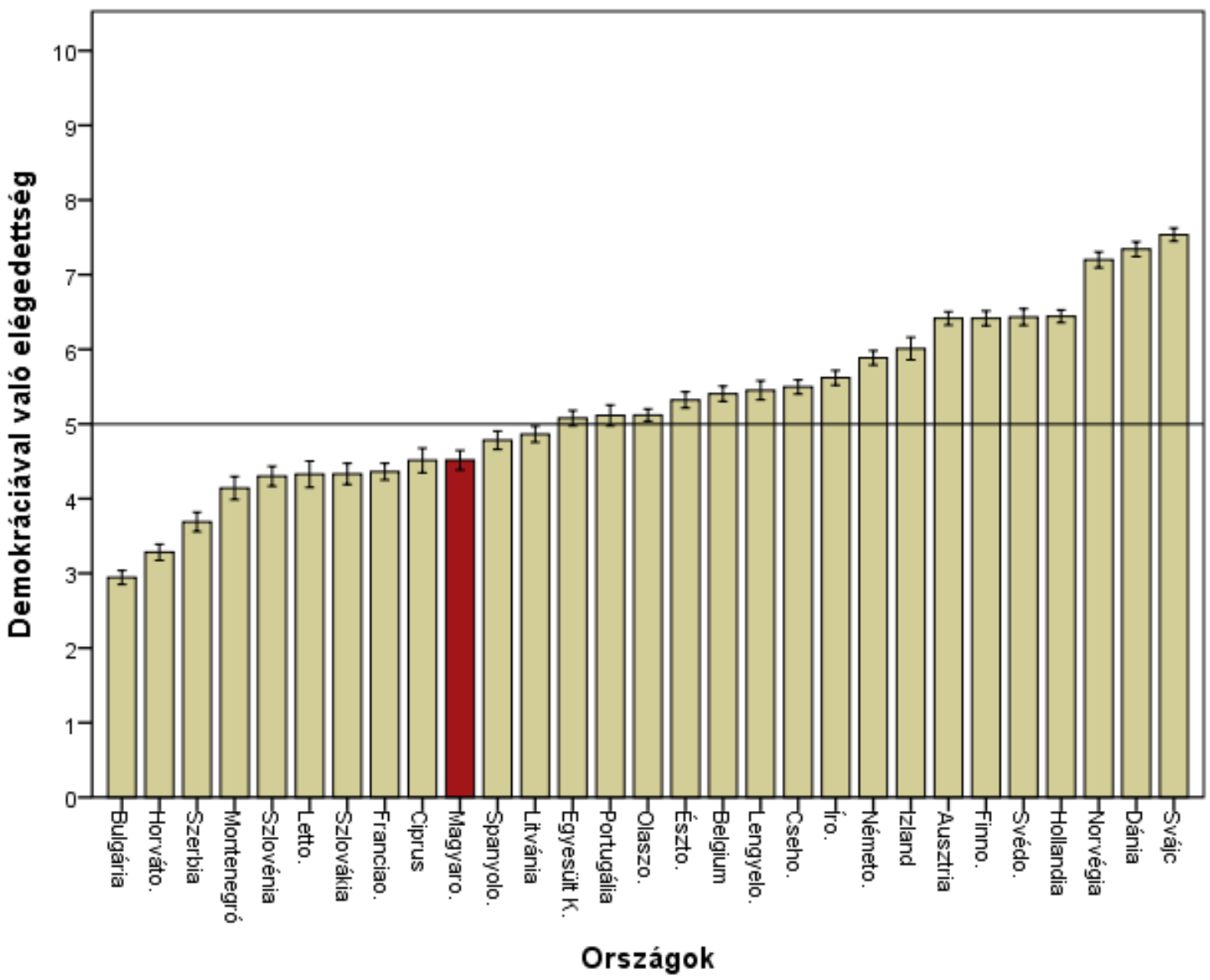

Forrás: ESS 9.

\section{A demokráciával való elégedettség trendjei 2002-2018}

A European Social Survey legutolsó, 2018-as adatfelvételében (ESS 9. hullám) 29 ország közül 12 található a 0-10 közötti skála közepénél lejjebb, vagyis inkább elégedetlen a demokráciával, 15 pedig vagy épp a skála közepénél helyezkedik el, vagy afelett található. Három országban (Bulgáriában, Horvátországban és Szerbiában) az emberek demokráciával való elégedetlensége magasnak mondható, hiszen az országos átlagértékek nem érik el a 4-et, kilenc ország esetében pedig az átlagértékek 4 és 5 között szóródnak. Az átlagok Norvégiában $(7,2)$, Dániában $(7,3)$ és Svájcban $(7,5)$ a legmagasabbak (1. ábra).

Általánosságban elmondható, hogy a kelet-európai országokban az elégedettség átlaga alacsonyabb, mint a nyugat- vagy észak-európai államokban, ugyanakkor akad néhány kivétel is. A nyugati országok közül Franciaország, míg a déli országok közül Ciprus és Spanyolország is a kevéssé elégedett országok közé tartozik, ugyanakkor a középkelet-európai és balti országok közül Csehország, Lengyelország és Észtország az elégedettebb országok közé sorolhatóak (az átlagaik meghaladják az 5-ös értéket, sorrendben 5,5; 5,5; 5,3), azonban a 10 legelégedettebb ország között egyetlen középkelet-európai vagy balti ország sem található.

Magyarországon az elégedettség átlaga 4,5, tehát az emberek átlagosan inkább elégedetlenek a demokrácia állapotával, amivel a mérsékelten elégedetlen országok közé és az országok sorrendjében a középmezőny aljához tartozik. 


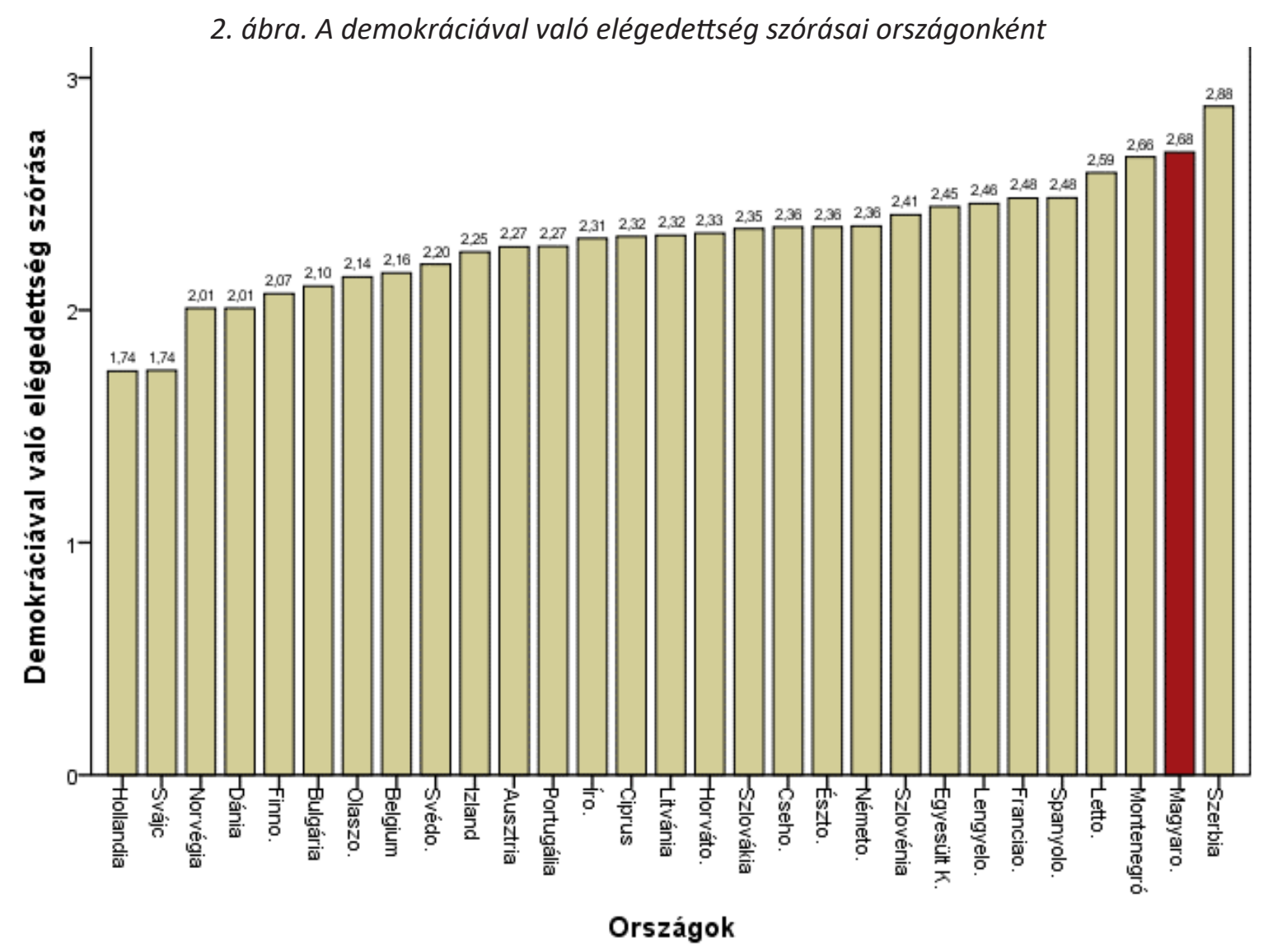

Forrás: ESS 9

Az országok átlagértékein túl érdemes megvizsgálni a demokráciával való elégedettség szórásait is. A szórás ugyanis megmutatja, mekkora az elégedettség kapcsán a közmegegyezés mértéke. Az alacsonyabb szórás arra utal, hogy az emberek inkább egyetértenek, míg a nagyobb szórás arra, hogy az emberek véleménye nagyobb mértékben eltér az átlagtól. Minél nagyobb egy országban a demokráciával kapcsolatos vélemények szórása, annál nagyobb a polarizáció mértéke. A 2. ábrán az elégedettség szórásait mutatjuk be.

A legnagyobb konszenzust (legalacsonyabb polarizáltságot, vagyis legkisebb szórást) Hollandiában $(1,74)$ és Svájcban $(1,74)$ láthatunk, míg a legeltérőbbek a vélemények Szerbiában $(2,88)$ és Magyarországon $(2,68)$. A 3. és 4. ábra együttesen azt mutatja, hogy azokban az országokban, ahol magasabb a demokrácia múködésével való elégedettség szintje, ott a vélekedések szórása kisebb, és fordítva, ahol az elégedettség átlaga alacsonyabb, a szórás magasabb. (Az átlagok és szórások közötti korreláció magas: -0,63).

Ettől a mintázattól érdekes eltérést mutat Bulgária, ahol a demokráciával való alacsony elégedettségi szintről viszonylagos konszenzus alakult ki (alacsony átlag és szórás jellemzi). Lengyelországot az inkább elégedett országok közé soroltuk, ugyanakkor Lengyelország a nagyobb szórású országok közé tartozik, tehát a magasabb elégedettség egy alacsonyabb szintű konszenzussal jár együtt.

Magyarországon a demokráciával való elégedettség középértéknél alacsonyabb, de nem kiemelkedően alacsony szintet mutat, ugyanakkor az egyik leginkább polarizált ország ezen a területen. A demokráciával való közepes elégedettség átlagához tehát extrém magas szórás párosul, hiszen a társadalmon belül a vélemények a demokrácia állapotáról jelentősen eltérnek. Sokan vannak olyanok, akik nagyon elégedettek a demokrácia müködésével, míg jelentős az ettől lényegesen eltérő véleményt megfogalmazók aránya is. Ennyire extrém eltérés az átlagok és a szórások között unikális a 2018-as adatfelvételben. 


\section{Az elégedettség és a polarizáltság változása}

Az eddig bemutatott adatok a 2018-as helyzetet írják le. Érdekes azonban megvizsgálni, hogyan változott 2002 óta a demokráciával való elégedettség és a demokrácia körüli egyetértés (a polarizáltság) szintje (Függelék 5. ábra). Kérdés tehát az, hogy a fent leírt eltérés az átlagok és a szórások között Magyarországon egy egyszeri, akár valamilyen adatfelvételi sajátosságból adódó hibának tudható be, vagy egy tartós folyamatról, a magyar társadalom egyedi jellegzetességről beszélhetünk.

Az utóbbi időszakban a legtöbb vizsgált országban növekedett vagy stagnált a demokráciával való elégedettség szintje. Jól láthatóan szinte minden országban volt változás, törés a 4-5. hullám időszakában, ami egybeesik a 2008-2009-es gazdasági válság elsődleges hatásainak érzékelésével.

Magyarországon az elégedettség az első hullám (adatfelvétel: 2002. október) és a negyedik hullám (adatfelvétel: 2009. január) között folyamatosan csökkent, majd a 2010-es választások (5. hullám, adatfelvétel: 2010. október) után növekedni kezdett. 2010 óta a demokráciával való elégedettség terén csak kisebb, nem tendencia jellegú elmozdulások rögzíthetők.

A vélemények polarizáltsága Magyarországon ugyanakkor folyamatos növekedést mutat. Míg 2002-ben az első hullámban vizsgált 22 ország közül Magyarország a 8. legmagasabb szórással rendelkezett, a 2018-as kilencedik hullámban már a második legmagasabbal a vizsgált 29 ország közül. Ezek az eredmények tehát azt mutatják, hogy 2010 óta a társadalom egy részében a demokráciával való elégedettség erősen növekedni kezdett, míg egy másik részében csökkent, így összességében az elégedettség átlaga kisebb mértékben változott.

Ha a trendeket a posztszocialista és a nyugat-európai (minden más 1990 előtt demokratizálódott ország) országok átlagával hasonlítjuk össze (3. ábra bal oldala), akkor látható, hogy Magyarországon a demokráciával való elégedettség átlaga inkább a kelet-európai régió átlagához és trendjéhez hasonlít, mint a nyugati mintázathoz.

\section{3. ábra. A demokráciával való elégedettség átlagai és szórásai Kelet- és Nyugat-Európában, valamint Ma-} gyarországon, ESS1-ESS9 hullám (2002-2018)
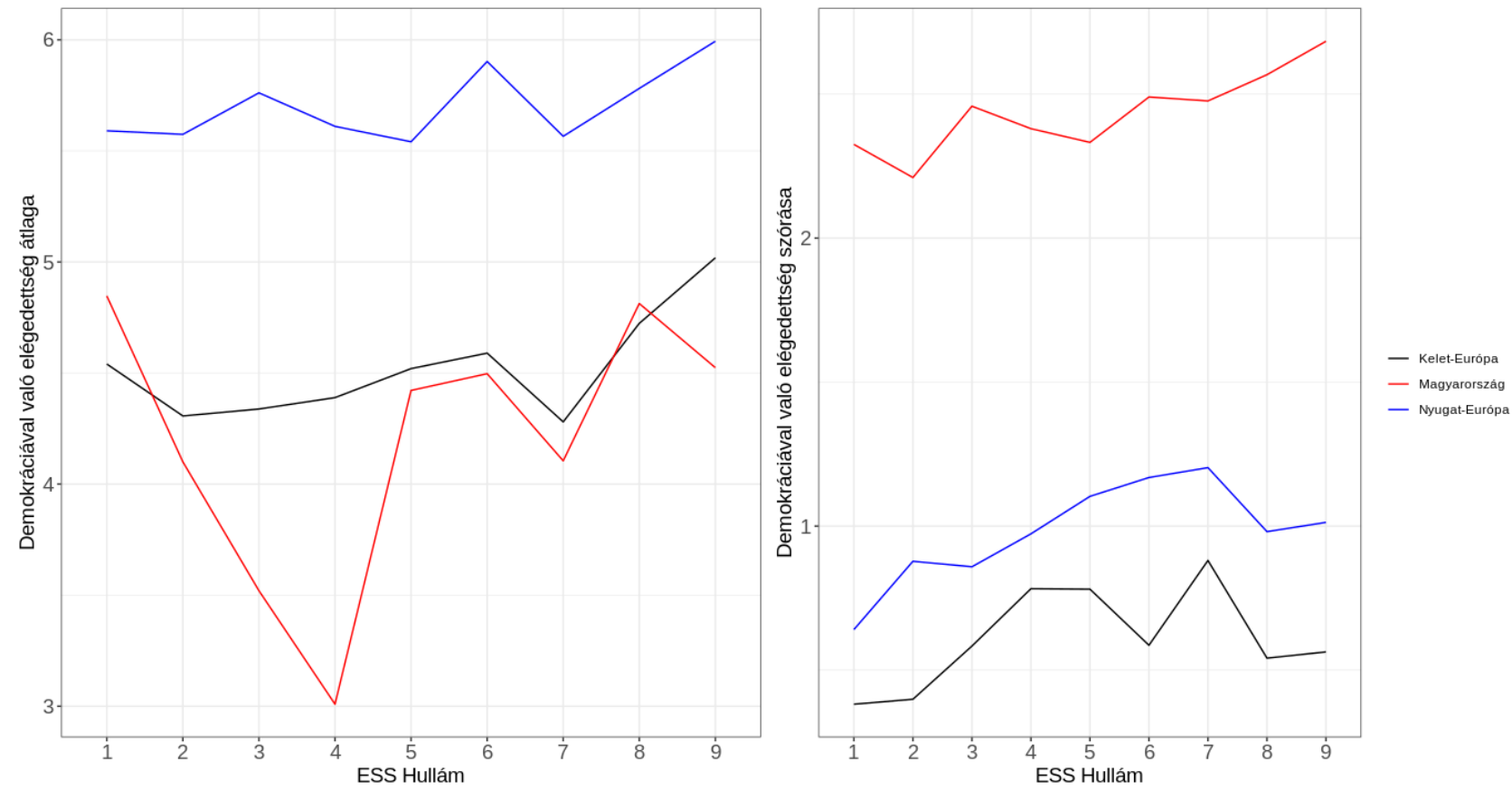

Forrás: ESS 01-09. 
A vélemények polarizációja azonban (3. ábra jobb oldala) minden ESS hullámban jóval magasabb volt Magyarországon, mint a nyugat-európai és a kelet-európai átlag, ráadásul míg a 7. hullám óta (2014) Európában inkább csökken a polarizáltság, Magyarországon erőteljesen emelkedik. A demokrácia múködését illető polarizáció tehát a 2010 után hatalomra jutó Fidesz-KDNP-kormányok időszakában kezdett el még jobban elszakadni mind a nyugati, mind pedig a közép-európai országok polarizációs mintáitól. Úgy véljük, hogy ez az eltérés magyarázatra szorul.

Ahogy erre Szabó és Oross (2019) rámutattak, a magyar kormánypárti szavazók viselkedése a polarizációs elméleteknek megfelelő. 2010-ig is megfigyelhető volt, hogy a mindenkori kormánypárti beállítódásúak kedvezőbben ítélték meg a demokrácia múködését, mint a társadalom többi tagja, vagy mint a legnagyobb támogatottságú ellenzéki párt támogatói, de - ahogy erre Patkós (2019) világosan rámutatott - 2010 után a Fidesz-KDNP-szavazóinak véleménye markánsabban eltér a társadalmi átlagtól, mint korábban (4. ábra). Az ESS

\section{4. ábra. A demokráciával való elégedettség átlagai és a kormánypárti, *illetve az ellenzéki** szavazók átla- gai Magyarországon, ESS1-ESS9 hullám (2002-2018)}

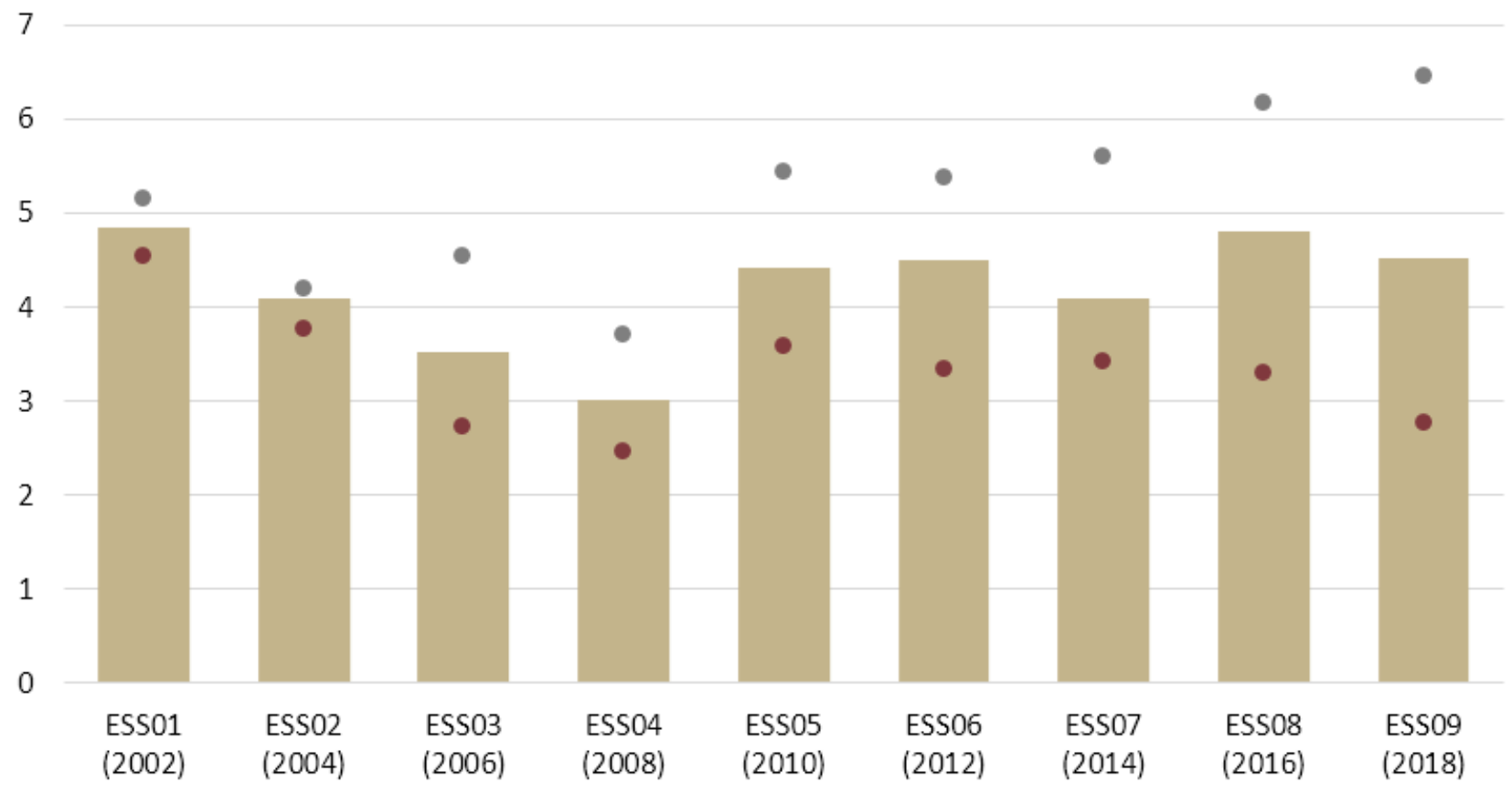

— demokráciával való elégedettség átlaga • kormánypárti szavazó átlaga • ellenzéki szavazó átlaga

*kormánypárti szavazó: az előző választáson az aktuális kormánypártokra szavazott.

**ellenzéki szavazó: legnagyobb támogatottságú ellenzéki párt listájára szavazott az előző választáson ${ }^{1}$ Forrás: ESS 01-09. ${ }^{2}$

1 Legnagyobb ellenzéki párt 2002: Fidesz-MPSZ; 2004: Fidesz-MPP; 2006: Fidesz-MPP; 2008: Fidesz-MPP; 2010: MSZP; 2012: MSZP; 2014: Kormányváltók (MSZP-DK-Együtt-PM-MLP); 2016: Kormányváltók (MSZP-DK-Együtt-PM-MLP); 2018: Jobbik.

$2 \mathrm{Az}$ adatfelvételek tényleges időpontjai:

ESS01 (eszmei időpont: 2002); tényleges adatfelvételi időpont: 2002. 10. - 2002. 12., választási év.

ESS02 (eszmei időpont: 2004); tényleges adatfelvételi időpont: 2005. 04. - 2005. 06.

ESSO3 (eszmei időpont: 2006); tényleges adatfelvételi időpont: 2006. 11. - 2007. 01., választási év.

ESS04 (eszmei időpont: 2008); tényleges adatfelvételi időpont: 2009. 02. - 2009. 04.

ESS05 (eszmei időpont: 2010); tényleges adatfelvételi időpont: 2010. 10. - 2010. 12., választási év.

ESS06 (eszmei időpont: 2012); tényleges adatfelvételi időpont: 2012. 11. - 2013. 02.

ESS07 (eszmei időpont: 2014); tényleges adatfelvételi időpont: 2015. 04. - 2015. 06.

ESS08 (eszmei időpont: 2016); tényleges adatfelvételi időpont: 2017. 05. - 2017. 09.

ESS09 (eszmei időpont: 2018); tényleges adatfelvételi időpont: 2019. 02. - 2019. 05. 


\section{5. ábra. Az aktuális kormánypárti és a legnagyobb támogatottságú ellenzéki párt szavazói véleményének különbsége a demokráciával való elégedettség társadalmi átlagától Magyarországon, ESS1-ESS9 hullám (2002-2018)}

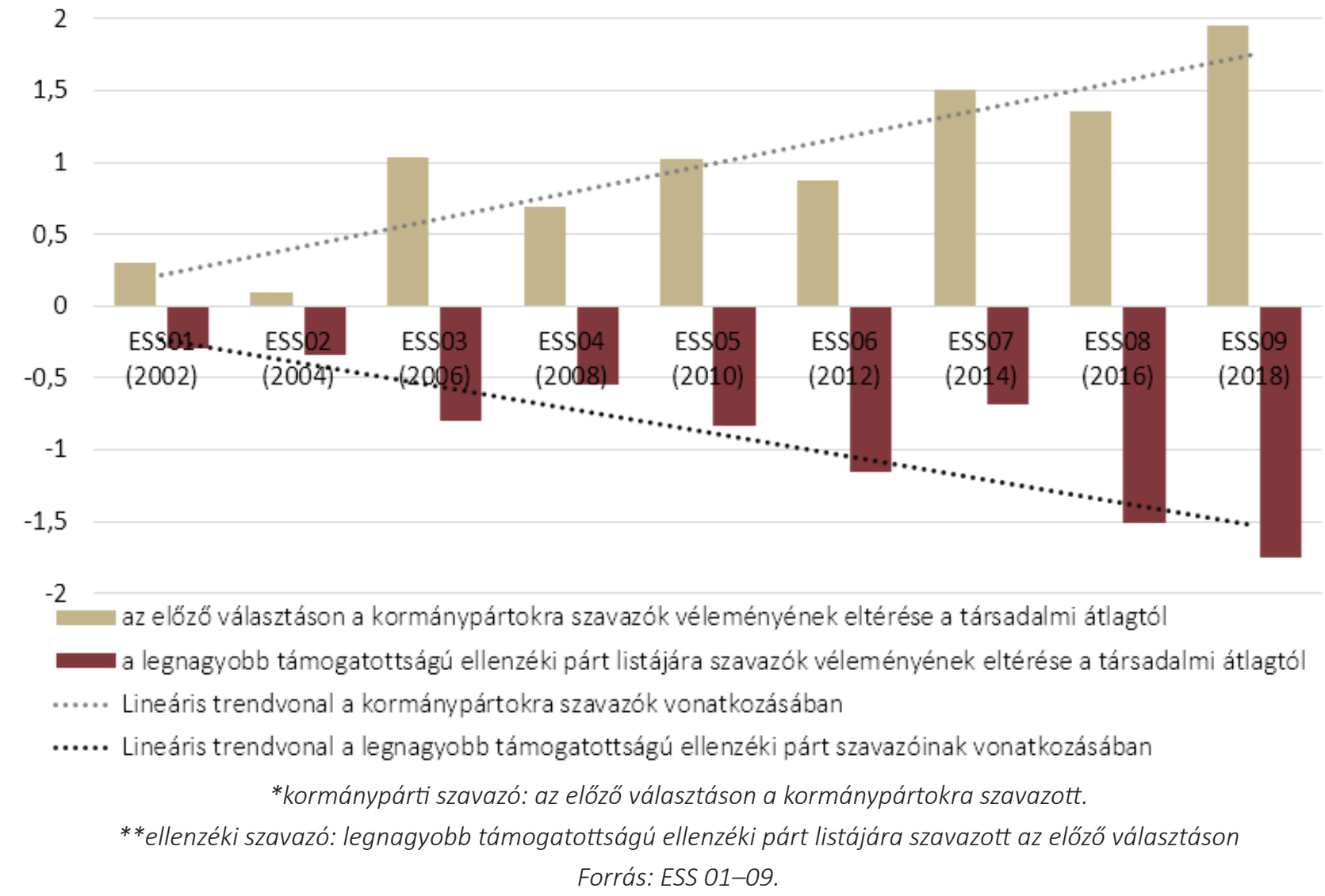

6. hullámától (2012) kezdődően a kormánypárti szavazók elégedettsége szinte lineárisan növekedett, az időszak végére a demokrácia múködésével való elégedettségük teljesen elszakadt az átlagos vélekedéstől (4. ábra). Az ESS 9. hullámában a társadalmi átlag és a kormánypárti szavazók demokráciával való elégedettségi átlaga között a valaha mért legmagasabb, 1,91 átlagpontnyi különbség mutatható ki (5. ábra). Bíró-Nagy (2019:64) szerint a magyar demokrácia minőségének percepciójával kapcsolatosan „párhuzamos valóságok” léteznek, „az ellenzéki és a kormánypárti szimpatizánsok mintha két különböző ország politikai berendezkedéséről nyilvánítottak volna véleményt."

A párhuzamos valóságok létezését erősíti az is, hogyha a legnagyobb támogatottságú ellenzéki párt/pártszövetség szavazóinak véleményét vizsgáljuk, ugyanis azt látjuk, hogy míg az első két hullámban az ellenzéki szavazók véleménye alig különbözött a teljes társadalmi átlagtól és a kormánypárti szavazókétól, addig 2006ban markáns szubjektívelégedettség-különbség mutatható ki, ami 2008-ra szúkült valamennyivel. A polarizáció érdemi növekedése 2010 után kezdődött, amikortól az ellenzéki szavazók következetesen és egyre fokozódó mértékben váltak elégedetlenebbé a demokráciával a társadalom egészéhez képest. 2018-ban nemcsak a kormánypárti szavazók véleménye volt a legtávolabb a társadalmi átlagtól, de legnagyobb ellenzéki pártra szavazóké is (5. ábra).

A két blokk, tehát a kormánypárti és a legnagyobb támogatottságú ellenzéki párt szavazói közötti véleménykülönbséget mérő polarizációs index 2004-ben volt a legkisebb (0,44 átlagpont), és 2008 óta eltérő intenzitással, de folyamatosan növekvő tendenciát mutat. A legnagyobb, extrém méretű különbség a két választói réteg véleményében az utolsó, 9. hullámban volt kimutatható (3,7 átlagpont). 
Ezek az eredmények jól alátámasztják a nagyfokú és növekvő mértékú pártos polarizációt Magyarországon (Patkós 2017, 2019). Véleményünk szerint ez az erősödő folyamat azonban nem csak a politikai rendszer megítéléséből következik, hanem a demokráciának mint fogalomnak az eltérő értelmezéséből is. Elfogadjuk tehát azt az vélekedést, hogy a különböző szavazók másként látják a demokráciát és annak megvalósulását, ami részben összefügg a rendszer teljesítményéről alkotott vélekedésekkel is.

A következőkben ennek megfelelően azt vizsgáltuk, hogy a pártos polarizáció eredményeként ténylegesen mást jelent-e Magyarországon a demokrácia egy ellenzéki és mást egy kormánypárti szavazó számára. Vagyis pontosan azt elemeztük, hogy a megvalósult demokrácia értelmezésében van-e különbség az egyes szavazói csoportok között, vagy mélyebb, tehát értelmezési különbségekről is beszélhetünk. Azt feltételeztük, hogy a kormánypárti szavazók és az ellenzéki beállítódásúak más-más szóval azonosítják a demokráciát, ami végső soron meghatározza a múködésével kapcsolatos attitúdjeiket is. Ennek a hipotézisnek a vizsgálatára az MTA TK PTI Választáskutatási panel 03. hullámának demokráciával kapcsolatos szóasszociációinak elemzését hívtuk segítségül.

\section{A demokrácia szóasszociációinak vizsgálata}

Elemzésünk most következő második részében függő változónk egy olyan kategoriális változó volt, amelyet a következő nyitott kérdés kódolásával állítottunk elő: „Kérem, mondja meg, hogy mi az az első és egyetlen szó, ami eszébe jut a következő kifejezésről: 'demokrácia'?" A választ a kérdezőbiztosnak szó szerint kellett rögzítenie.

Az úgynevezett szóasszociációs kérdés során a kérdezetteknek egy lehetőségük van saját álláspontjuk kifejtésére. Bár szólnak érvek amellett, hogy legyen kettő vagy akár több válaszlehetőség, tapasztalataink szerint, a második vagy a harmadik válaszlehetőség során exponenciálisan növekszik a válaszelhagyók aránya. Voltak olyan válaszolók, akik nem csak egy szóval, hanem több szóból álló szókapcsolattal azonosították a demokráciát. A kódolás során ezeket két vagy három válaszként rögzítettük. Ahogy az 1. táblázatból kitűnik, míg az egyszavas, illetve egymáshoz kapcsolódó egy-két szavas, de egyjelentésű említések száma 1098, a két- vagy többjelentésű említések száma összesen 42, azaz statisztikailag elhanyagolható számú volt. Épp ezért az elemzés során az első említéseket vettük figyelembe.

A kódolás első lépéseként nyelvileg tisztítottuk a szöveget, azaz az alapvető helyesírási, elírási problémákat javítottuk, majd második lépésként szófelhőt készítettünk az így kapott szövegtestből (6. ábra). A szófelhő világosan kijelölte azokat a válaszokat, amelyek alapján az azonos jelentéstartalmú szavakat összevonhattuk: ezek az 1.) egyenlőség, 2.) szabadság, 3.) népuralom/népakarat, 4.) szólásszabadság, 5.) vélemények szabadsága/véleménynyilvánítás, 6.) választás, 7.) nép, valamint 8.) a bizonytalan és válaszmegtagadó válaszok.

Az összevonás során a kutatásban részt vevő 3 kutató egymástól függetlenül összevonta a szavakat, szókapcsolatokat a szófelhő alapján. Az összevonások folyamatos egyeztetésen mentek keresztül. Az azonos öszszevonás elfogadásra került, és az iterálás addig folytatódott, amíg az alábbi 11 konszenzusos kategória össze nem állt. (Az összevonás menetéhez lásd a Függelék 1. táblázatát.) Az egyes végső kategóriák egy kivétellel - szabadság - több kifejezés összevonásából jöttek létre. Szóasszociáció helyett éppen ezért érdemesebb szóösszetételt alkalmazni. 
6. ábra. Mi jut eszébe a demokrácia kifejezésröl?

Eredeti, tartalmi összevonás nélküli szófelhö, $N=1093$

véleménynyilvánítás

szabadnép népakarat

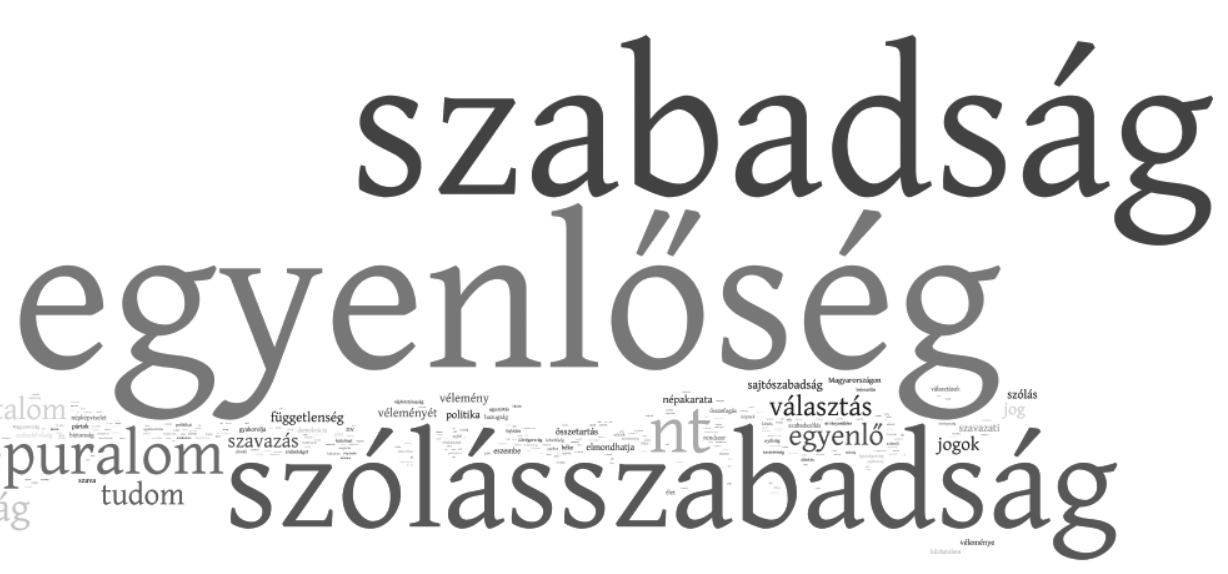

Egyenlőség emlitettsége összevonások nélkül: 137, szabadság emlitettsége összevonások nélkül:118, szólásszabadság emlitettsége összevonások nélkül: 86.

Forrás: MTA TK V2018-3.

Az 1. táblázat mutatja, hogy a magyar társadalom milyen szavakkal, szóösszetételekkel azonosítja a demokráciát.

1. táblázat. A demokráciával kapcsolatos szóasszociációk megoszlása (3 válasz alapján)

\begin{tabular}{|l|l|c|}
\hline & szókapcsolat & említés (\%) \\
\hline 1 & egyenlőség, egyenjogúság & 19 \\
\hline 2 & nép, emberek & 17 \\
\hline 3 & politikai szabadságjogok & 14 \\
\hline 4 & szabadság & 12 \\
\hline 5 & demokrácia múködtetése, demokrácia intézményei (benne a választás) & 10 \\
\hline 6 & nem létezik, Magyarországon nincs ilyen & 5 \\
\hline 7 & beleszólás az ügyekbe, megértés, összefogás & 5 \\
\hline 8 & függetlenség, szuverenitás, Fidesz & 4 \\
\hline 9 & érzelmi alapú megközelítések (pozitív és negatív is) & 3 \\
\hline 10 & materiális megközelítés & 1 \\
\hline 11 & semmi, nincs válasz & 11 \\
\hline & $\mathrm{N}$ & 1098 \\
\hline
\end{tabular}

Forrás: MTA TK V2018-3.

Feltűnő, hogy az 1789-es Nagy Francia Forradalom „Szabadság, Egyenlőség, Testvériség (Liberté, Égalité, Fraternité)" hármas jelszavából milyen erőteljesen köszön vissza a szabadság és az egyenlőség. A szabadság az egyetlen olyan szó, amely teljesen önállóan, más szavak, szóösszetételek nélkül önmagában került be a legfontosabb kifejezések listájára, és az egyenlőség a legnagyobb arányban választott szóösszetétel.

A táblázat alapján látható, hogy a demokráciafelfogásban a részvételi aspektus egyoldalú. A politikai részvétel egyes, eltérő bevonódást, egyéni és kollektív felelősséget és befektetést igénylő típusai közül kizárólag a választás, a választói jog, a kormány választásokon keresztüli leválthatósága jelenik meg. A választás és a rokonértelmű, hozzá kapcsolódó kifejezések önmagukban 5\%-át tették ki a szóasszociációknak. A részvételi aspektus hiánya, illetve egyoldalúsága egyébként megfelel Kovács (2017) egyetemisták között végzett kutatási eredményeinek. 
Árnyalja a fenti alapállítást (miszerint a demokrácia a magyar társadalom számára egy klasszikus, inkább liberális demokrácia felfogáshoz áll a legközelebb), hogy a második leggyakoribb kategória a nép, a népuralom, néphatalom, emberek uralma, ami az utóbbi évtizedben a populizmus legfontosabb hívószavává vált (BöcskeiHajdu 2019, Müller 2018, Tallár 2017) jelentős politikatudományi vitákat generálva a demokrácia értelmezéséről, átalakulásáról és jelentéséről. Fontos azonban jelezni, hogy Magyarországon 1947 és 1990 között olyan államszocialista rendszer múködött, amelynek államformája népköztársaság volt, így a nép fogalma a társadalmi kollektív emlékezetben a populizmustól eltérő módon is megmaradhatott. Ezt az érvelést ugyanakkor gyengíti, hogy a népköztársaság kifejezés mindössze két alkalommal szerepel a szóasszociációkban.

Egy másik szempont is felmerül a nép, népuralom kapcsán. Ha ennyire magas az említettsége, ebből akár következhetne a közéleti, politikai részvételre való igény is. A „nép hatalma” összekapcsolódhatna azzal is, hogy az emberek aktívan alakítani akarják a környezetüket. Ez az igény azonban a demokrácia fogalmának értelmezésekor egyértelműen elmaradt, hiszen csak a választási részvételhez kapcsolódó asszociációk jelentek meg a válaszokban. Elképzelhető ugyanakkor, hogy ha a válaszadóink második-harmadik asszociációit is ismernénk, akkor az állampolgári aktivitáshoz kapcsolódó fogalmak is előkerültek volna, de vizsgálatunk erre nem terjedt ki.

Jól látszik, hogy a válaszok alapján nincs egy domináns kifejezés, ami alapvetően leírná a magyar társadalom demokráciaértelmezését. Több, nagyjából azonos fontosságú kifejezésről beszélhetünk, amelyek kevésbé a konkrét magyar helyzetet jelzik, mint inkább általában, elvontan, tankönyvi értelemben utalnak a demokráciára.

Ehhez a megállapításunkhoz kapcsolódóan, feltűnő az is, hogy mennyire alacsony a demokrácia érzelmi jellegú megközelítése (3\%). Ebbe a csoportba olyan válaszokat soroltunk, amelyek (1) valamilyen indulati jellegük miatt erősebb érzelmi háttérre utalhatnak, vagy (2) jeleznek egyfajta érzelmi alapú viszonyt a demokráciához. Önmagában már az szokatlan, hogy a pozitív és a negatív tartalmú kifejezések (amelyek még nem is biztos, hogy hordoznak érzelmi jelleget) egy kategóriába sorolódnak. Ennek oka, hogy külön-külön szinte elhanyagolható az arányuk. A pozitív és a negatív kifejezések közül egyébként inkább a negatívak („marhaság”, hülyeség”, „baromság”, „korrupció” „viszálykodás”) a gyakoribbak. A pozitív asszociációk mögötti érzelmi elköteleződés még áttételesebb (Magyarország, hazaszeretet stb.).

Végül - és ez kifejezetten meglepő eredmény -, a szóasszociáció során a demokráciát nem vagy csak alig-alig azonosították a kérdezettek materiális, anyagi jóléthez kapcsolódó kifejezésekkel (pl. gazdagság, jólét, pénz). Ezzel nem azt állítjuk, hogy a jóléttel, gazdasági teljesítménnyel kapcsolatos vélemények ne lennének jelen a demokrácia teljesítményének megítélésekor, sokkal inkább azt, hogy amikor meg kell fogalmazni a demokrácia esszenciáját, nem ez az elsődleges szempont, vagyis nem ez az első szó, ami az emberek eszébe jut.

A kutatás eredményei szerint a demokrácia jelenleg sokkal inkább politikai töltetű, mint gazdasági jellegú fogalom. Korábban, így a rendszerváltás folyamatában készített empirikus kutatások még azt jelezték, hogy szemben a többi közép-európai országgal, a magyarok a demokrácia szó hallatán inkább szociális és gazdasági jólétre gondoltak, míg a többi országban a szabadságjogok érvényesülése lényegesen fontosabb, sőt meghatározó jelentőségú volt. Ezt támasztotta alá a Times Mirror, East-West Attitude Survey eredménye is (Bruszt-Simon 1992; Bruszt 1995). Az 1991-ben készült adatfelvétel jelezte, hogy a vizsgált 12 ország közül messze a lengyelek és a magyarok körében volt a legmagasabb a materiális jólét iránti vágy és az állami paternalizmus elfogadottsága.

Kérdés azonban, hogy azzal, hogy a demokrácia jelenleg politikai töltetű fogalom, megszűnt-e annak gazdasági konnotációja, vagy a társadalom „tisztánlátása” növekedett. Kétségtelen ugyanis, hogy a demokrácia alapját nyújtó politikai alrendszer elkülönül a gazdasági rendszertől és annak teljesítményétől. Ennek a kérdésnek a megválaszolására a tanulmány végén egy regressziós modell elemzése során visszatérünk. 
A szóasszociációkkal kapott demokráciaértelmezés jól összecseng a korábbi magyarországi kvantitatív kutatásokkal. A demokrácia szóasszociációi ugyanis fontos részeken fedik le a Hunyady és munkatársai által felsorolt demokráciaértelmezést. Ezt az állítást támasztja alá, hogy a Választáskutatási panel 3. hullámában a kérdezettek 57\%-a a demokráciát tartotta minden politikai rendszernél jobbnak, 31\% volt a rendszerszkeptikusok aránya (ők „az Önhöz hasonló emberek számára az egyik politikai rendszer olyan, mint a másik” válaszlehetőséget jelölték meg), míg a diktatúrát bizonyos körülmények között elfogadók aránya 11\%-ot tett ki. A szóasszociációk és a politikai berendezkedés közötti választás is azt jelzi, hogy 2018-ban a demokrácia fontos volt a magyar társadalom számára.

A következőkben azt vizsgáltuk meg, hogy a demokráciához kapcsolódó fogalmak, a demokrácia értelmezése miben különbözik az egyes pártok szavazói között. Ehhez elsőként a 11 kategóriából álló szóasszociációs változót 8 kategóriába vontuk össze. Majd az egyes demokráciaasszociációs csoportokat a válaszadók pártpreferenciái szerint mutatjuk be. Végül, multinomiális logisztikus modell segítségével azt vizsgáltuk, milyen faktorokkal, tényezőkkel függnek össze a demokráciához kapcsolódó asszociációk.

\section{Eltérések a demokrácia szóasszociációiban}

A 7. ábra alapján a 10 szóasszociációs kategória5 (a válaszhiányt, nem tudja kategóriát nem vontuk be az elemzésbe) egymástól jelentős mértékben elkülönülő csoportokat alkot. A nép (17\%), a szabadságjogok (14\%), a szabadság (12\%) és az egyenlőség (19\%) egy-egy önálló, egymástól igen távol álló értelmezés, együttesen az összes válasz 62\%-át képviseli. A többi hat szóasszociáció az origó körül szóródik egymástól nehezen elválasztható módon, ezért erre a hat kategóriára egy új modellt futtattunk, amely további 3 kategóriát, a demokrácia intézményeit, a beleszólás jogát, valamint a „nincs demokráciát” különítette el, míg a materiális, érzelmi és a szuverenitással kapcsolatos megközelítések továbbra is határozottan együtt, az origó körül találhatók. Ez utóbbi három kategóriát összevontuk, és megmaradt az adathiány is.

\section{7. ábra. A szóasszociációk ALSCAL-modelljei}
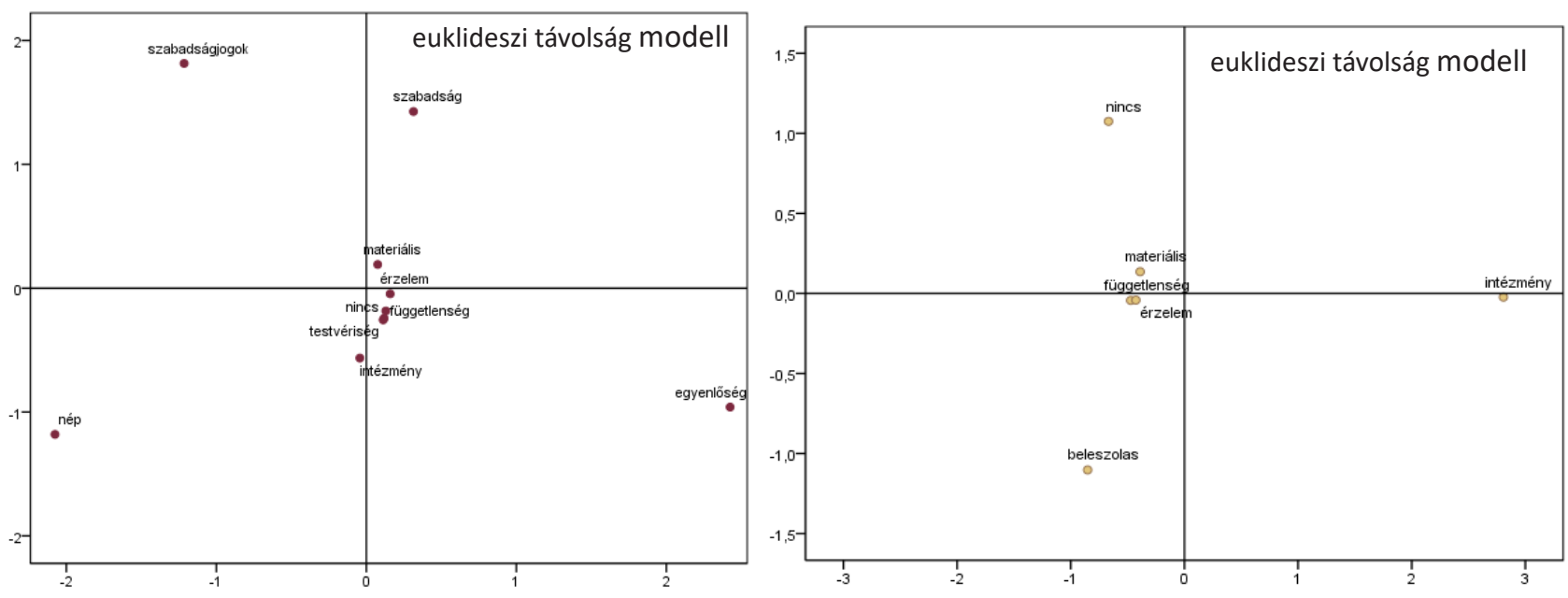

Stress: 0,$11 ; R S Q: 0,95763$

SQ: 0,97923

Forrás: MTA TK V2018-3.

5 A több, 1-2\%-os kategória miatt nehézkes lenne a kategóriák részletesebb elemzése, ezért többdimenziós skálázás (ALSCAL-modell) segítségével a szóasszociációk közötti kapcsolatot egy kétdimenziós síkon ábrázoltuk (7. ábra), megvizsgálva, hogy milyen módon kapcsolódnak vagy éppen távolodnak el egymástól a szóasszociációk. 


\section{8. ábra. A demokráciával kapcsolatos szóasszociációk összevont kategóriái (\%)}

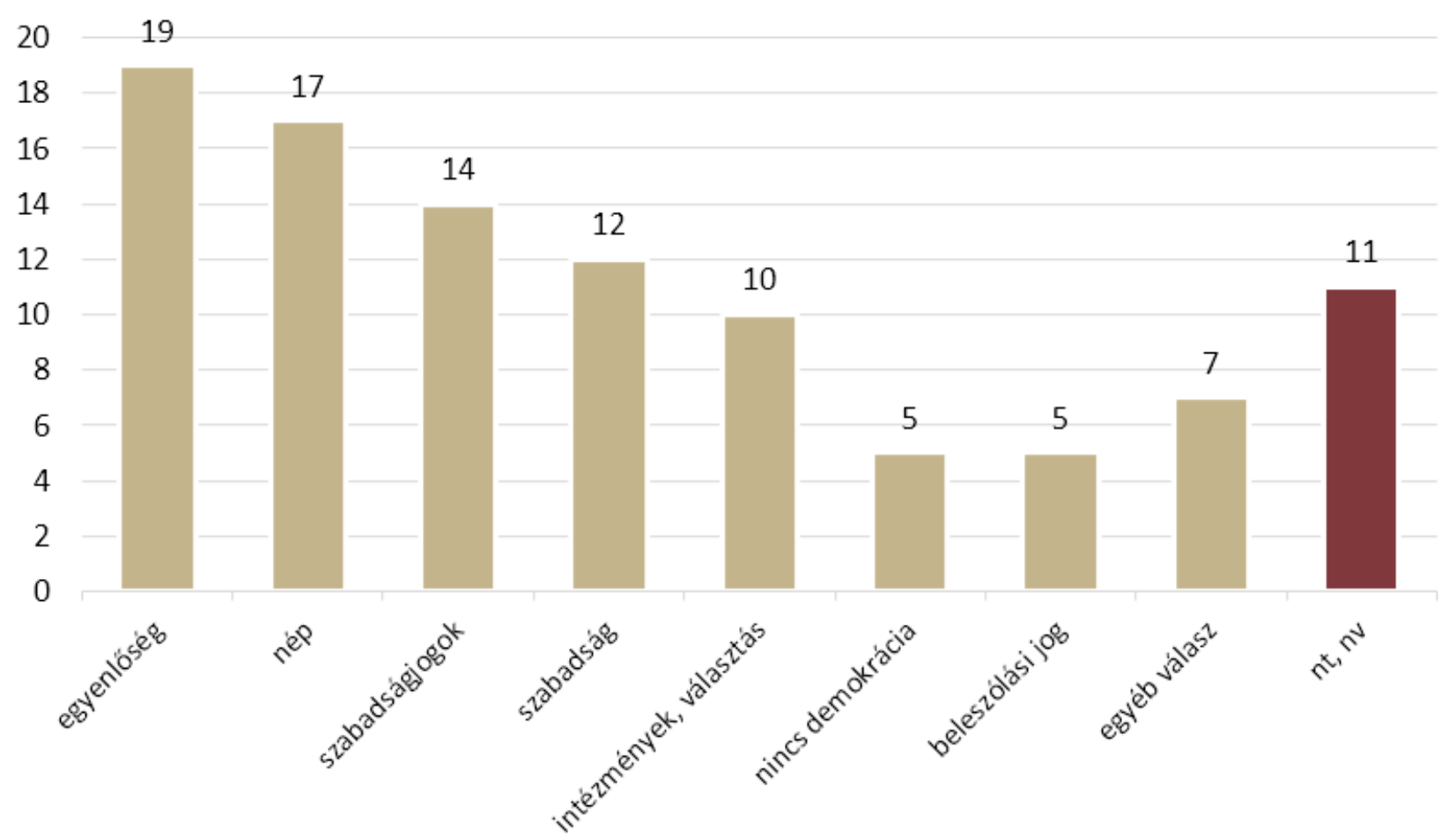

Az összevonások végére tehát a következő kategóriák alakultak ki (8. ábra). A tanulmány további részében ezeket a kategóriákat elemezzük.

A Fidesz-KDNP szavazók esetében - a standardizált adjusztált reziduálisok alapján - az átlaghoz képest kevéssé valószínű, hogy a válaszhiányt, illetve az „ilyen nem létezik Magyarországon” kategóriát használták a demokrácia értelmezéseként, és ezzel párhuzamosan az átlagoshoz képest némileg magasabb körükben a „népet" választók aránya (2. táblázat).

A 2018-as választásokon második legnagyobb párt, a Jobbik szavazóira ezzel ellentétben épp a magyarországi demokrácia negativ értelmezése valamint a döntésbe való beleszólás iránti vágy jellemző nagyobb valószínűséggel.

A baloldali pártok ${ }^{6}$ szavazóinak válaszai hasonlítanak leginkább az átlagos válaszokhoz, a marginálisoknál szereplő eredményekhez. Érdekes még, hogy e pártok szavazói az átlagosnál kisebb mértékben asszociáltak a „beleszólás” kifejezésre. A liberális, zöld és kisebb pártok (LMP, Momentum, MKKP) szavazói az egyenlőséggel valamivel nagyobb valószínűséggel azonosították a demokráciát, mint az átlag, de ez az összefüggés csak 0,1-es szignifikanciaszinten szignifikáns. Végül, az ismeretlen pártpreferenciájúak (nem tudja melyik pártra szavazzon, nem mondja meg, hogy melyik pártra szavaz, valamint nem menne el a választásokra) az átlagosnál kevésbé tudták bármivel is azonosítani a demokráciát. 


\section{2. táblázat. A szóasszociációk választottsága pártpreferenciák szerint} (oszlopszázalék és adjusztált reziduálisok*)

\begin{tabular}{|c|c|c|c|c|c|c|}
\hline & $\begin{array}{l}\text { Fidesz- } \\
\text { KDNP }\end{array}$ & Jobbik & $\begin{array}{l}\text { baloldali } \\
\text { pártok }\end{array}$ & $\begin{array}{l}\text { liberális, } \\
\text { zöldpártok }\end{array}$ & $\begin{array}{l}\text { ismeretlen } \\
\text { pártpreferen- } \\
\text { cia }\end{array}$ & $\begin{array}{c}\text { Összesen } \\
\%\end{array}$ \\
\hline egyenlőség & $\begin{array}{l}20 \\
0,8\end{array}$ & $\begin{array}{r}15 \\
-1,3\end{array}$ & $\begin{array}{c}18 \\
-0,2\end{array}$ & $\begin{array}{l}27 \\
1,9\end{array}$ & $\begin{array}{c}17 \\
-0,7\end{array}$ & 19 \\
\hline nép & $\begin{array}{l}20 \\
1,7 \\
\end{array}$ & $\begin{array}{r}16 \\
-0,6 \\
\end{array}$ & $\begin{array}{c}13 \\
-1,4 \\
\end{array}$ & $\begin{array}{r}15 \\
-0,5 \\
\end{array}$ & $\begin{array}{c}17 \\
-0,1 \\
\end{array}$ & 17 \\
\hline politikai szabadságjogok & $\begin{array}{l}14 \\
0,1\end{array}$ & $\begin{array}{l}17 \\
1,1\end{array}$ & $\begin{array}{c}17 \\
1 \\
\end{array}$ & $\begin{array}{c}7 \\
-1,6 \\
\end{array}$ & $\begin{array}{r}13 \\
-0,8 \\
\end{array}$ & 14 \\
\hline szabadság & $\begin{array}{l}13 \\
0,9\end{array}$ & $\begin{array}{c}9 \\
-1,1 \\
\end{array}$ & $\begin{array}{l}13 \\
0,3 \\
\end{array}$ & $\begin{array}{l}18 \\
1,6 \\
\end{array}$ & $\begin{array}{r}10 \\
-1,2\end{array}$ & 12 \\
\hline $\begin{array}{l}\text { intézmények, választás, } \\
\text { működés }\end{array}$ & $\begin{array}{l}10 \\
0,2\end{array}$ & $\begin{array}{c}7 \\
-1,4 \\
\end{array}$ & $\begin{array}{l}10 \\
0,1\end{array}$ & $\begin{array}{l}12 \\
0,6 \\
\end{array}$ & $\begin{array}{l}11 \\
0,5 \\
\end{array}$ & 10 \\
\hline beleszólás & $\begin{array}{c}6 \\
1,1\end{array}$ & $\begin{array}{c}8 \\
2,1\end{array}$ & $\begin{array}{c}1 \\
-2,2 \\
\end{array}$ & $\begin{array}{c}8 \\
1,0\end{array}$ & $\begin{array}{c}2 \\
-1,9\end{array}$ & 5 \\
\hline $\begin{array}{l}\text { nincs ilyen } \\
\text { Magyarországon }\end{array}$ & $\begin{array}{c}1 \\
-4,4 \\
\end{array}$ & $\begin{array}{l}10 \\
3,6 \\
\end{array}$ & $\begin{array}{c}5 \\
0,5 \\
\end{array}$ & $\begin{array}{c}6 \\
0,5 \\
\end{array}$ & $\begin{array}{c}6 \\
1,3 \\
\end{array}$ & 5 \\
\hline egyéb válasz & $\begin{array}{c}8 \\
-0,1 \\
\end{array}$ & $\begin{array}{l}10 \\
1,3\end{array}$ & $\begin{array}{c}9 \\
0,6 \\
\end{array}$ & $\begin{array}{c}4 \\
-1,0 \\
\end{array}$ & $\begin{array}{c}6 \\
-0,9 \\
\end{array}$ & 8 \\
\hline $\begin{array}{l}\text { válaszhiány, } \\
\text { semmi sem jut eszébe }\end{array}$ & $\begin{array}{c}8 \\
-2,2 \\
\end{array}$ & $\begin{array}{c}8 \\
-1,3 \\
\end{array}$ & $\begin{array}{c}14 \\
1 \\
\end{array}$ & $\begin{array}{c}3 \\
-2,2 \\
\end{array}$ & $\begin{array}{l}17 \\
3,9\end{array}$ & 11 \\
\hline pártok támogatottsága & 39 & 16 & 13 & 6 & 26 & 100 \\
\hline mindösszesen & 100 & 100 & 100 & 100 & 100 & 100 \\
\hline
\end{tabular}

* 1 feletti, vagy -1 alatti érték a marginálishoz képest statisztikailag szignifikáns eltérésre utal. Minél nagyobb a reziduális, annál jobban eltér az adott cella értéke az átlagos megoszlástól.

Pearson $\mathrm{Chi}^{2}=91,050 ;$ sig=0,000; Cramers $^{\prime} \mathrm{V}=0,144$

Forrás: MTA TK V2018-3.

Az elemzés következő lépéseként azt vizsgáltuk meg, hogy a demokrácia szóasszociációinak választásával milyen tényezők függnek össze. Ehhez egy multinomiális regressziós modellt illesztettünk.

A 2. táblázat alapján az egyes szavak választását - a multinomiális logisztikus regressziós modell szerint több társadalmi hátteret leíró bevont változóval (nem, fővárosi vagy sem; diplomás vagy sem; demokráciapárti vagy sem; kormánypárti, ellenzéki vagy ismeretlen preferenciájú) magyaráztuk. A függő változó referenciakategóriája a nem tudja megmondani, hogy mi a demokrácia, vagy nem akarja megmondani, mit ért a demokrácián, vagyis nincs érdemi demokráciaértelmezése.

Azokhoz képest, akik nem tudják érdemben értelmezni a demokráciát, a demokráciát az egyenlőséggel azonosítják inkább a nők (a férfiakhoz képest), a diplomások (a nem diplomásokhoz képest), a fővárosiak (a vidéken élőkhöz képest), a demokráciát a legjobb politikai rendszernek tekintők (a diktatúrapártiakhoz képest), valamint a kormánypártiak (az ismeretlen pártpreferenciájúakhoz képest) (3. táblázat). A szabadságot a diplomások, a demokraták, valamint a kormánypárti szavazók választják nagyobb valószínúséggel azokhoz képest, mint akik nem tudják, hogy mi a demokrácia, illetve a saját referenciakategóriájukhoz képest.

A referenciakategóriához képest a népet, mint a demokrácia asszociációját a diplomások, a kormánypártiak, valamint a demokraták választják. A szabadságjogok választása a demokraták, a kormánypártiak és az ellenzéki szavazók körében mutat szignifikáns összefüggést. Az, hogy nincs demokrácia (Magyarországon), egyértelműen az ellenzéki szavazók szóasszociációja (Béta=2,323), míg a demokráciát múködtető intézményeket, 
beleértve a választást, egy önmagát demokratának tartó értelmiségi csoport választja (Béta=3,239).

Azzal a szóasszociációval, hogy a demokrácia nem más, mint együttmúködés és beleszólás az ügyek közös intézésébe a diplomások, a demokraták, a Fidesz-KDNP-szavazói, valamint az ellenzékiek azonosultak inkább azokhoz képest, mint akiknek nincs demokráciaértelmezése. Végül, az „egyéb” kategória megnevezése politikai preferenciák függvénye, hiszen a bizonytalan pártpreferenciájúakhoz képest a kormánypártiaknál (Béta=2,345) és ellenzékieknél (Béta=2,356) szignifikáns összefüggést mutat a modell.

3.. táblázat. A szóasszociációk választásának multinomiális logisztikus regressziós modelljeinek Béta értékei (szignifikáns kapcsolatok alapján)*7

\begin{tabular}{|l|c|c|c|c|c|c|c|c|c|c|}
\hline & $\begin{array}{c}\text { egyen- } \\
\text { lőség }\end{array}$ & $\begin{array}{c}\text { szabad- } \\
\text { ság }\end{array}$ & nép & $\begin{array}{c}\text { szabad- } \\
\text { ságjogok }\end{array}$ & $\begin{array}{c}\text { nincs de- } \\
\text { mokrácia }\end{array}$ & $\begin{array}{c}\text { intézmé- } \\
\text { nyek }\end{array}$ & $\begin{array}{c}\text { bele- } \\
\text { szólás }\end{array}$ & $\begin{array}{c}\text { egyéb } \\
\text { ref=nem tudja mi a demokrácia, vagy nem akarja megmondani mi a demokrácia }\end{array}$ \\
\hline Tengelymetszet & $-1,024$ & $-1,537$ & NS & $-1,179$ & $-1,235$ & $-1,151$ & $-2,587$ & $-1,465$ \\
\hline nem=nő & 1,911 & 1,444 & 1,190 & 1,222 & 1,429 & 1,092 & 1,382 & 1,561 \\
\hline diploma=diplomás & 2,644 & 2,903 & 3,630 & 2,196 &, 526 & 2,940 & 2,800 & 2,215 \\
\hline Bp. vagy sem=fővárosi & 2,294 & 1,716 &, 866 & 1,652 &, 398 &, 954 & 1,215 & 1,008 \\
\hline $\begin{array}{l}\text { demokráciapárti= } \\
\text { demokráciát tekinti } \\
\text { legjobb rendszernek }\end{array}$ & 2,758 & 3,748 & 1,849 & 3,981 & 1,439 & 3,239 & 2,982 & 1,538 \\
\hline kormánypárti** & 2,173 & 2,391 & 2,178 & 2,007 &, 413 & 1,739 & 3,881 & 2,345 \\
\hline ellenzéki** & 1,649 & 1,870 & 1,436 & 1,821 & 2,323 & 1,378 & 3,030 & 2,356 \\
\hline
\end{tabular}

*szignifikáns összefüggés félkövérrel $p \leq 0,05$ esetén.

**ref=ismeretlen pártpreferencia (nem tudja, nem válaszol, passziv).

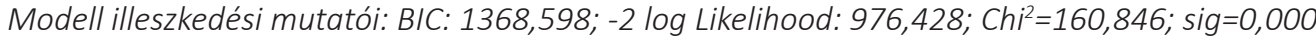

Goodness-of-Fit: Pearson Chi²: 427,467; sig=0,000

Pseudo R²: Cox and Snell: 0,136; Nagelkerke: 0,138;

Forrás: MTA TK V2018-3.

Mit is jelentenek a fenti megállapítások? Jól láthatóan az adatfelvétel időszakában, 2018. május-június folyamán, a harmadik kétharmados Fidesz-KDNP győzelmet követően, az ellenzéki és a kormánypárti szavazók, valamint az ismeretlen preferenciájúak demokráciaértelmezésében lényeges különbségek voltak. A kormánypártiak válaszai két kivételtől eltekintve mindenütt szignifikánsan eltértek az ismeretlen preferenciájúak álláspontjától. Egyetértettek abban, hogy nincs, vagy legalábbis Magyarországon nincs demokrácia, illetve, hogy a demokrácia nem más, mint az azt múködtető intézmények, szereplők, beleértve a jogállamot, a pártokat és a választás aktusát. A kormánypártiak tehát viszonylag szofisztikáltan, több szempontból is azonosulnak a demokráciával.

Ezzel szemben az ellenzékiek véleményéből egyfajta politikai kiábrándultság tűnik ki: nincs Magyarországon demokrácia, illetve a demokrácia a politikai szabadságjogokkal és az ügyek közös intézésével azonos. Az is feltűnő az eredmények alapján, hogy 2018-ban a diplomások szóasszociációi közelebb állnak a Fideszszavazókéhoz, mint az ellenzékiekéhez. Ezekkel a sajátosságokkal érdemes lesz egy későbbi kutatás során újra foglalkozni.

A demokrácia értelmezése vélhetően nem független az aktuális politikai diskurzusoktól. A Fidesz-KDNP szavazói elsősorban a népet tartják fontosnak, amit nehéz függetleníteni a populizmus demokráciafelfogásától, amely a választásokat tartja a demokratikus felhatalmazás egyetlen forrásának (kissé sarkosan: az intézmények,

7 A teljes modellt a Függelék 2. táblázata mutatja. 
bíróság stb. nem legitimek, mert nem választotta azokat senki). Ennek tükrében nyeri el jelentőségét az ellenzéki szavazók véleménye, melyben egyrészt megjelennek az intézmények, másrészt, ha egy dolgot kell mondani, akkor könnyen juthat eszükbe az, hogy „nincs demokrácia”.

Az ESS adatokat ismertető részben bemutattuk, hogy a kormánypárti és az ellenzéki szavazók demokráciával való elégedettsége közötti távolság folyamatosan növekszik Magyarországon. A szóasszociációkat vizsgálva úgy túnik, hogy a két csoport közötti különbség nem csupán az elégedettség mértékét jelzi. Nem arról van tehát szó, hogy az ellenzéki szavazók elégedetlenebbek a magyarországi demokráciával, mint a kormánypártiak, ugyanis az ellenzéki pártokkal szimpatizálók szerint ma Magyarország politikai berendezkedése nem demokratikus. Ez a jelenség további kérdéseket vet fel: miből táplálkoznak ezek a vélekedések és hogyan alakultak ki? De ezek elemzésére és megválaszolására jelen cikkünkben nem vállalkozunk.

\section{A demokráciával való elégedettség regressziós modellje}

Elemzésünk végén lineáris regressziós modell segítségével azt vizsgáltuk, hogy mindezen ismeretek tükrében a demokráciával való elégedettséget (0-10 skála) milyen tényezők befolyásolják. A fentiekben ismertetett regressziós modell minden változóját szerepeltettük ebben a modellünkben is, továbbá betettük még plusz változóként a gazdasági helyzettel való elégedettséget. A modellekbe külön léptettük be az egyes független változókat. A negyedik modellbe (Modell 4) szerepeltettük a gazdasággal való elégedettséget, de a kormánypárti-ellenzéki dummy változót nem. Ezzel szemben az ötödik modellben (Modell 5) a kormánypárti-ellenzéki dummyt léptettük be, viszont a gazdasági elégedettséget kihagytuk.

Ahogy erre elemzésünk során többször rámutattunk, a demokrácia elsődleges szóasszociációja alapvetően politikai jellegű fogalmakat takar. A materiális jelentésű szavak, szókapcsolatok aránya elhanyagolható. Ez azonban nem jelenti azt, hogy közvetett módon, a demokráciával való elégedettséget mérlegelve a társadalom tagjai ne vennék figyelembe a gazdasági helyzetet, ezért végső modellünkbe (Modell 6) kontrollváltozóként bevontuk ezt az attitüdinális kérdést is. Valószínű ugyanis, hogy a további, második, harmadik asszociációk során előkerültek volna a gazdasággal, jólléttel kapcsolatos asszociációk is.

A 4. táblázat hat regressziós modell futtatásának eredményeit mutatja. Az első modellben csak a szóaszszociációk és a demokráciával való elégedettség közötti kapcsolatot vizsgáltuk, majd minden következő futtatás során újabb kontrollváltozót vontunk be. Először a szociodemográfiai változókat, majd a demokráciapárti, illetve diktatúrapárti beállítódást. A negyedik modell a gazdasági teljesítménnyel való elégedettség hatását is tartalmazza, az ötödik modellben pedig bevontuk a pártpreferenciát, Fidesz-KDNP és ellenzéki szavazók dichotómiában. Végül, a hatodik, teljes modellben az összes változót szerepeltettük.

A táblázat alján található statisztikai adatok alapján a hat modell közül az első három magyarázóereje alacsony és nagyjából azonos, a negyedik modelltől kezdődően azonban a társadalomtudományokban magasnak tekinthető, tehát az újonnan bevonásra kerülő függő változók jelentős mértékben magyarázzák a demokráciával való elégedettség összvarianciáját.

A regressziós vizsgálat szerint a demokrácia értelmezései közül kettő, a demokrácia = „nép”, valamint a demokrácia = „nem létezik Magyarországon” minden modellben szignifikáns kapcsolatban áll a demokráciával való elégedettséggel, akkor is, amikor más változókkal kontrolláljuk a hatásokat. Azok elégedettebbek a demokráciával, akik a néppel azonosítják azt (Béta=0,108 a teljes, 6. modellben), míg akik szerint nincs demokrácia Magyarországon, azok - teljesen logikus módon - nem elégedettek azzal (Béta=-0,075). 
4. táblázat. A demokráciával való elégedettség lineáris regressziós modelljei, Béta értékek

\begin{tabular}{|c|c|c|c|c|c|c|}
\hline$* p \leq 0,05$ & \multirow[b]{2}{*}{$\begin{array}{l}\text { Modell } 1 \\
\text { demokrá- } \\
\text { cia-értelme- } \\
\text { zések }\end{array}$} & \multirow[b]{2}{*}{$\begin{array}{l}\text { Modell } 2 \\
\text { szocio- } \\
\text { demográfiai } \\
\text { változók }\end{array}$} & \multirow[b]{2}{*}{$\begin{array}{l}\text { Modell } 3 \\
\text { demokrata }\end{array}$} & \multirow[b]{2}{*}{$\begin{array}{l}\text { Modell } 4 \\
\text { gazdasági } \\
\text { elégedett- } \\
\text { ség }\end{array}$} & \multirow[b]{2}{*}{$\begin{array}{l}\text { Modell } 5 \\
\text { politikai } \\
\text { preferencia }\end{array}$} & \multirow[b]{2}{*}{$\begin{array}{l}\text { Modell } 6 \\
\text { össz- } \\
\text { modell* }\end{array}$} \\
\hline $\begin{array}{l}* * p<0,01 \\
* * * p \leq 0,001\end{array}$ & & & & & & \\
\hline (Constant) & $3,717 * * *$ & $3,648 * * *$ & $3,775^{* * *}$ & $1,081 * * *$ & $2,465 * * *$ & 0,791 \\
\hline demokrácia=egyenlőség & 0,070 & 0,067 & 0,060 & 0,025 & 0,081 & 0,065 \\
\hline demokrácia=szabadság & $0,084^{*}$ & $0,083^{*}$ & 0,075 & 0,062 & $0,096 *$ & $0,092 *$ \\
\hline demokrácia=nép & $0,104 *$ & $0,107^{*}$ & $0,103 *$ & $0,072 *$ & $0,111^{* *}$ & $0,108^{* *}$ \\
\hline $\begin{array}{l}\text { demokrácia= szabadság- } \\
\text { jogok }\end{array}$ & $0,089 *$ & $0,088^{*}$ & 0,080 & 0,061 & $0,124^{* *}$ & $0,120 * *$ \\
\hline $\begin{array}{l}\text { demokrácia = nincs de- } \\
\text { mokrácia }\end{array}$ & $-0,156 * * *$ & $-0,155^{* * *}$ & $-0,155^{* * *}$ & $-0,102 * * *$ & $-0,067^{*}$ & $-0,075^{*}$ \\
\hline demokrácia=intézmény & 0,043 & 0,047 & 0,042 & 0,028 & 0,028 & 0,005 \\
\hline demokrácia=beleszólás & $-0,001$ & 0,001 & $-0,002$ & $0-, 010$ & $-0,014$ & $-0,011$ \\
\hline demokrácia=egyéb & 0,090 & 0,088 & 0,085 & 0,069 & $0,136^{*}$ & $0,130 *$ \\
\hline kor & & 0,019 & 0,018 & $-0,003$ & $-0,010$ & $-0,009$ \\
\hline budapesti vagy sem & & $-0,029$ & $-0,028$ & $-0,037$ & $-0,064^{*}$ & 0,030 \\
\hline $\begin{array}{l}\text { diplomája van vagy? } \\
\text { nincs }\end{array}$ & & 0,016 & 0,018 & 0,043 & 0,034 & $-0,044$ \\
\hline $\begin{array}{l}\text { demokráciapárti vagy } \\
\text { sem }\end{array}$ & & & $-0,038$ & $-0,046$ & $-0,039$ & 0,065 \\
\hline gazdasági elégedettség & & & & $0,555^{* * *}$ & --- & $0,398 * * *$ \\
\hline Fideszellenzék & & & & & $0,560 * * *$ & \\
\hline $\mathrm{R}^{2}$ & 0,033 & 0,034 & 0,036 & 0,332 & 0,323 & 0,425 \\
\hline F-próba & 4,570 & 3,450 & 3,929 & 41,883 & 30,554 & 41,788 \\
\hline sig & 0,000 & 0,000 & 0,000 & 0,000 & 0,000 & \\
\hline
\end{tabular}

Függő változó: Mennyire elégedett a demokrácia müködésével Magyarországon?

*A teljes modellt és statisztikáit részletesen a Függelék 3. táblázata.

Forrás: MTA TK V2018-3.

A negyedik modell arra mutat rá, hogy a gazdasági helyzettel való elégedettség nagyon erős hatással van a demokráciával való elégedettségre. Minél elégedettebb a kérdezett a gazdasági helyzettel, annál elégedettebb a demokráciával (Béta=0,555). Bár ez a hatás nagyon erős, a kutatás fontos eredménye, hogy a demokráciaértelmezések közül ennek ellenére kettő hatása is érvényesül önállóan (demokrácia=nép, demokrácia=nincs Magyarországon).

Az ötödik modellben, amikor a pártpreferenciát bevontuk, láthatóvá vált, hogy a politikai hovatartozás igen jelentős hatást gyakorol a demokráciával való elégedettségre (Béta=0,560). Nyilvánvaló összefüggésként a kormánypártra való szavazás nagyobb elégedettséggel jár együtt, a pártos polarizáció hatása tehát jelentősen érvényesül. Érdekes azonban, hogy ebben a modellben az öt demokráciaértelmezés is szignifikáns kapcsolatban áll a függő változóval: bár kontroll alatt tartottuk a pártpreferenciát, mégis jelentkezett önálló hatásuk.

Végül, a hatodik modellben, amikor minden változót bevontunk, kitűnt: leginkább az határozza meg, hogy ki mennyire elégedett a demokrácia múködésével, hogy mennyire elégedett a gazdaság helyzetével (Béta=0,398), valamint, hogy kormánypárti vagy ellenzéki szavazó-e (Béta=0,298). A két tényező közül a Béta, 
illetve a t-próba alapján a gazdasági elégedettség az erősebb hatású, azaz a gazdasági helyzetértékelés határozza meg leginkább a demokráciával való elégedettséget, de a pártos polarizáció hatása sem elhanyagolható. ${ }^{8} \mathrm{~A}$ modellben a demokráciaértelmezések közül szignifikáns hatású változó „a nép” és a „nincs ilyen Magyarországon”, a „szabadság”, a „szabadságjogok”, valamint az „egyéb” kategória is.

Érdemi újdonsága a kutatásunknak, hogy rámutatott, a demokrácia elsődleges szóasszociációjából ugyan kikoptak a materiális, egyéni jóléttel kapcsolatos szavak, ez azonban nem jelenti azt, hogy - mint fentebb látható, nagyon is jelentős mértékben - ne befolyásolnák a demokráciával való elégedettséget a gazdasági szempontok. A demokrácia megítélése tehát összekapcsolódik a gazdasági várakozásokkal és a teljesítmény megítélésével.

Kutatásunk fontos eredménye az is, hogy a demokrácia-szóasszociációk közül több is önállóan befolyásolta a demokrácia múködésével való elégedettséget. Van tehát annak jelentősége, hogy ki hogyan definiálja a demokrácia kifejezést.

\section{KONKLÚZIÓ}

Az elmúlt években a kutatók sokat foglalkoztak azzal, hogyan jellemezzék a Magyarországon kialakult illiberális politikai rendszert. Az elemzések általában a demokratikus berendezkedés változását a politikai rendszer szintjén írták le, és sokkal kevesebbet foglalkoztak azzal, hogy, ezekkel a változásokkal párhuzamosan változott-e az emberek demokráciáról alkotott vélekedése.

Tanulmányunk első részében az European Social Survey kutatási projekt adatait felhasználva bemutattuk, hogy Magyarországon a demokráciával való elégedettség átlaga, valamint a változó szórása a negyedik-ötödik hullám (2008-2010) óta növekszik, azaz bár az emberek átlagosan egyre elégedettebbek, a demokráciáról alkotott vélemények polarizációja lényegesen megnőtt az elmúlt években.

A magyarországi adatokat összevetettük az európai és a regionális átlagokkal is. Ez alapján azt láttuk, hogy Magyarországon a demokráciával való elégedettség átlaga nagyjából együtt mozog a kelet-európai országok átlagával, ugyanakkor az elégedettség szórása jóval magasabb, mint akár a kelet- akár a nyugat-európai régióban.

Összességében tehát Patkós Veronikával (2019) egyetértve azt mondhatjuk, hogy Magyarországon a politikai rendszerben lejátszódó folyamatok megítélésében az állampolgárok véleménye egyre növekvő mértékben eltérő. Vannak társadalmi csoportok, akik egyre elégedettebbek és vannak, akik egyre elégedetlenebbek a demokrácia múködésével kapcsolatban. A legfontosabb, legélesebb különbséget a kormánypárti és az ellenzéki szavazók között találjuk.

A nemzetközi szakirodalomban különbséget tesznek a tényleges és az ideális demokrácia fogalma között. A megvalósult demokrácia azt mutatja meg, hogy pillanatnyilag milyen a társadalom demokráciaérzékelése, míg az ideáltipikus demokráciafelfogás azt jelzi, hogy ideáltipikusan, egy elképzelt, jól múködő demokrácia milyen lenne (milyennek kellene lennie). Ezt a kétfajta megközelítést alkalmaztuk mi is. A klasszikus (pártos) polarizációs megközelítésen megpróbáltunk túllépni azzal, hogy az elégedettségek polarizációja mellett, a demokráciaértelmezések polarizációját is beemeltük vizsgálatunkba.

Elemzésünkben szóasszociációval vizsgáltuk a demokrácia jelentését. Azt tapasztaltuk, hogy a demokrácia értelmezésében a szabadságnak, a polgári szabadságjogoknak, az egyenlőségnek és a népnek, népképviseletnek, valamint a demokráciát múködtető intézményeknek és aktoroknak van a legnagyobb jelentősége. E kategóriák az összes válasz több mint héttizedét tették ki. 
Innovativ eredménye a kutatásunknak, hogy megállapítottuk, a demokrácia elsődleges asszociációjából 2018-ra kikoptak, illetve jelentősen háttérbe szorultak a gazdasági, materiális szempontok, mint a jólét, a pénz, a munka, a fejlődés. Ez azonban nem jelenti azt, hogy a demokráciával való elégedettség mérlegelésekor a magyar társadalom ne venné figyelembe a gazdasági teljesítményt. Sőt, többváltozós regressziós modellünk alapján a gazdasági teljesítmény pozitív megítélése világos összefüggést mutatott a demokráciával való elégedettséggel. Ebből arra is következtethetünk, hogy a nemzetközi szakirodalommal összhangban, a megvalósult, valamint az ideálisnak tekintett demokrácia elválik egymástól.

A demokráciával való elégedettség a pártos polarizációs elméleteknek megfelelően politikai preferencia függvénye is: a kormánypárti szavazók jóval elégedettebbek a demokráciával, mint az ellenzékiek. Azonban nemcsak a megvalósult demokrácia, hanem - és ez szintén újdonságnak tekinthető - az ideális demokrácia leírásakor, azaz a szóasszociációk vonatkozásában is érvényesül a pártosság. A Fidesz-KDNP-szavazói más szavakkal, szókapcsolatokkal írták le a demokráciát, mint a 2018 nyarán erősen kiábrándultnak tűnő ellenzéki szavazók.

A kormánypártok szavazóinak a demokrácia szóról nagy valószínűséggel jutott eszébe valamilyen konkrét politikai érték, valamint kis valószínűséggel jutott az eszükbe róla a demokrácia hiánya, vagy valamilyen demokratikus intézmény (pl. bíróságok, választások). Ezzel szemben az ellenzéki szavazók alig különböztek azoktól a pártpreferenciával nem rendelkező állampolgároktól, akik nem tudtak semmire sem asszociálni a demokrácia szó kapcsán. Két konkrét érték jutott eszükbe nagyobb valószínűséggel, a közügyekbe való beleszólás és a különböző szabadságjogok.

Az ESS adatok tehát azt mutatják, hogy a demokráciával való elégedettség tekintetében nagyon polarizált a magyar társadalom, de tanulmányunk második fele rámutatott arra is, hogy a kormánypárti és az ellenzéki szavazók demokráciaértelmezése is nagyon jelentősen eltér. 


\section{HIVATKOZÁSOK}

Anderson, C. J. - Blais, A. - Bowler, S. - Donovan, T. - Listhaug, O. (2005) Losers' Consent. Oxford University Press. http://dx.doi.org/10.1093/0199276382.001.0001.

Berggren, H. M. - Fugate, G. A. - Preuhs, R. R. - Still, D. R. (2004) Satisfied? Institutional Determinants of Citizen Evaluations of Democracy. Politics \& Policy, 32(1), 72-96. http://dx.doi.org/https://doi.org/10.1111/j.1747-1346.2004.tb00176.x.

Bernauer, J. - Vatter, A. (2012) Can't get no satisfaction with the Westminster model? Winners, losers and the effects of consensual and direct democratic institutions on satisfaction with democracy: can't get no satisfaction with the westminster model? European Journal of Political Research, 51(4), 435-468. http://dx.doi.org/10.1111/j.1475-6765.2011.02007.x.

Bíró-Nagy A. (2019) Párhuzamos valóságok: a demokrácia minőségének percepciója Magyarországon. In Böcskei B. - Szabó A. (szerk.) Hibrid rezsimek. A politikatudomány X-aktái. Budapest: MTATK TPI - Napvilág, 59-76.

Bogaards, M. (2018) De-democratization in Hungary: diffusely defective democracy. Democratization, 25(8). 1481-1499.

Bozóki A. - Hegedűs D. (2017) A kívülről korlátozott hibrid rendszer. Az Orbán-rezsim a rendszertipológia tükrében. Politikatudományi Szemle, 2. 7-32.

Böcskei B. - Hajdu N. (2019) Demokráciák, szürke zónák, hibrid rezsimek - egy terminológiai Bábel megmászása. In Böcskei B. - Szabó A. (szerk.) Hibrid rezsimek. A politikatudomány X-aktái. Budapest: MTATK TPI - Napvilág. 17-34.

Böcskei B. - Szabó A. (szerk.) (2019) Hibrid rezsimek. A politikatudomány X-aktái. Budapest: MTA TK PTI - Napvilág.

Bruszt L. - Simon J. (1992) A Nagy Átalakulás. Elméleti megközelítések és állampolgári vélemények a demokráciáról és a kapitalizmusról. Politikatudományi Szemle, 1, 75-98.

Bruszt L. (1995): Miért támogatnák a kapitalizmust a kelet-európaiak? Politikatudományi Szemle 3, 41-73.

Buzogány, A. (2017) Illiberal democracy in Hungary: authoritarian diffusion or domestic causation? Democratization, 24 (7), 13071325. http://dx.doi.org/10.1080/13510347.2017.1328676.

Canache, D. (2012) Citizens' Conceptualizations of Democracy: Structural Complexity, Substantive Content, and Political Significance. Comparative Political Studies, 45 (9), 1132-1158. http://dx.doi.org/10.1177/0010414011434009.

Curini, L. - Jou, W. - Memoli, V. (2012) Satisfaction with Democracy and the Winner/Loser Debate: The Role of Policy Preferences and Past Experience. British Journal of Political Science, 42 (2), 241-261. http://dx.doi.org/10.1017/S0007123411000275.

Dahlberg, S. - Linde, J. (2016) Losing Happily? The Mitigating Effect of Democracy and Quality of Government on the Winner-Loser Gap in Political Support. International Journal of Public Administration, 39 (9), 652-664. http://dx.doi.org/10.1080/01900692.2016.1177831.

Dalton, R. J. - Shin, D. C. - Jou, W. (2007) Popular conceptions of the meaning of democracy: Democratic understanding in unlikely places. Irvine: University of California, Irvine, Center for the Study of Democracy. Elérhető: http://escholarship.org/uc/ item/2j74b860

Easton, D. (1965) A Systems Analysis of Political Life. New York: Wiley.

Gunther, R. - Montero, J.R. (2004) Attitudes toward democracy in seven countries: dimensional structure and behavioral correlates. Studies in Public Policy, 385.

Enyedi, Zs. (2016) Populist Polarization and Party System Institutionalization: The Role of Party Politics in De-Democratization. Problems of Post-Communism, 63(4), 210-220. http://dx.doi.org/10.1080/10758216.2015.1113883

Heyne, L. (2019) Democratic demand and supply: a spatial model approach to satisfaction with democracy. Journal of Elections, Public Opinion and Parties, 29 (3), 381-401. http://dx.doi.org/10.1080/17457289.2018.1544904.

Hunyady Gy. (2015) A demokrácia-követelmények a köztudatban és a társadalmi atmoszféra ambivalenciája. In Hunyady Gy. - Berkics M. (szerk.) A jog pszichológiája. A hiányzó láncszem. Budapest: ELTE Eötvös Kiadó, 281-335.

Huszár Á. - Berger V. (2020) Az új középosztály? Politikatudományi szemle, 29 (2), 71-99. http://dx.doi.org/10.30718/POLTUD.HU.2020.2.71.

Kornberg, A. - H. D. Clarke. (1992) Citizens and Community. Political Support in a Representative Democracy. Cambrigde. Cambridge University Press.

Kovács T. (2017) Támogatás, közöny és kritika: látkép a hallgatók demokráciához füződő viszonyáról. In Szabó A. - Oross D. (szerk.) Csendesek vagy lázadók?: A hallgatók politikai orientációi Magyarországon (2011-2015). Budapest Szeged: Belvedere Meridionale, MTA TK PTI, 77-98.

Kriesi, H. - Saris, W. - Moncagatta, P. (2016) The Structure of Europeans' Views of Democracy. In Ferrín, M. - Kriesi, H. (szerk.) How Europeans View and Evaluate Democracy. Oxford University Press, 64-89. 
Lijphart, A (1999) Patterns of Democracy. Government Forms and Performance in Thirty-Six Countries. New Haven/London: Yale University Press.

Linde, J. - Ekman, J. (2003) Satisfaction with democracy: A note on a frequently used indicator in comparative politics. European Journal of Political Research, 42 (3), 391-408. http://dx.doi.org/10.1111/1475-6765.00089.

Linz, Juan (1988) Legitimacy of democracy and the socioeconomic system. In Dogen, M. (szerk.) Comparing Pluralist Democracies. Boulder: Westview Press, 63-112.

Lipset, S. M. (1959) Some Social Requisites of Democracy: Economic Development and Political Legitimacy. American Political Science Review, 53 (1), 69-105.

Merkley, E. - Cutler, F. - Quirk, P. J. - Nyblade, B. (2019) Having Their Say: Authority, Voice, and Satisfaction with Democracy. The Journal of Politics, 81 (3), 848-861. http://dx.doi.org/10.1086/702947.

Messing V. - Szabó A. - Róbert P. - Ságvári B. (2013) (szerk.) A magyar társadalom demokráciaképe: ESS Magyarország Gyorsjelentés I. 1-42. Budapest: MTA Társadalomtudományi Kutatóközpont, 2013., ESS Magyarország Gyorsjelentés 2013, ISBN:978-9637372-87-2.

Mishler, W. - Rose, R. (1997) Trust, Distrust and Skepticism: Popular Evaluations of Civil and Political Institutions in Post-Communist Societies. Journal of Politics, 59 (2), 418-51.

Müller, J. W. (2018) Mi a populizmus. Budapest: Libri.

Osterberg-Kaufmann, N. - Stark, T. - Mohamad-Klotzbach, C. (2020) Challenges in conceptualizing and measuring meanings and understandings of democracy. Zeitschrift Für Vergleichende Politikwissenschaft, 14 (4), 299-320. http://dx.doi.org/10.1007/s12286-020-00470-5.

Pickel, S. - Breustedt, W. - Smolka, T. (2016) Measuring the quality of democracy: Why include the citizens' perspective? International Political Science Review, 37 (5), 645-655. http://dx.doi.org/10.1177/0192512116641179.

Powell, G. B. Jr. (1982) Contemporary Democracies: Participation, Stability, and Violence. Cambridge: Harvard University Press.

Patkós V. (2017) Politikai polarizáció és gazdasági sikertelenség az európai demokráciákban Politikatudományi Szemle 4. $29-52$.

Patkós V. (2019) Szekértáborharc - Eredmények a politikai megosztottság okairól és következményeiről Budapest: Napvilág.

Róbert P. - Oross D. - Szabó A. (2017) Youth, Precarious Employment and Political Participation in Hungary. Intersections: East European Journal of Society And Politics 3(1), 120-146.

Schedler, A. - Sarsfield, R. (2007) Democrats with adjectives: Linking direct and indirect measures of democratic support. European Journal of Political Research, 46, 637-659.

Shin, D.Ch. (1999) Politics and culture in democratizing Korea. New York, NY: Cambridge University Press.

Susánszky P. - Tóth G. (2018) Számítanak az elvek is? Az elégedetlenség szerepe a politikai tiltakozásokban. Socio.hu Társadalomtudományi szemle, 2, 24-45.

Szabó A. - Oross D. (2019) Két modell között? A politikai rendszerek megítélése és a politikai aktivizmus mintázatai Magyarországon. In: Böcskei B. - Szabó A. (szerk.) Hibrid rezsimek. A politikatudomány X-aktái. Budapest, MTATK TPI - Napvilág Kiadó, 35-57.

Tallár F. (2017) Populizmusok és demokráciák, avagy a politika újraácsolt színpada. Politikatudományi Szemle 1, 107-131. http://www. poltudszemle.hu/szamok/2017_1szam/tallar.pdf

Tilly, C. (2007) Democracy. New York: Cambridge University Press. 
FÜGGELÉK

F1. táblázat. A demokráciával kapcsolatos szóasszociációk összevonásának folyamata

\begin{tabular}{|c|c|c|c|c|}
\hline összevont kategória & $\begin{array}{l}\text { kapcsolódó* kategó- } \\
\text { riák } 1 .\end{array}$ & $\begin{array}{l}\text { kapcsolódó kategó- } \\
\text { riák } 2 .\end{array}$ & $\begin{array}{l}\text { kapcsolódó kategó- } \\
\text { riák } 3 .\end{array}$ & $\begin{array}{l}\text { kapcsolódó kategó- } \\
\text { riák } 4 .\end{array}$ \\
\hline egyenlőség & egyenjogúság & esélyegyenlőség & egyenlő jogok & \\
\hline \multicolumn{5}{|l|}{ szabadság } \\
\hline nép & népakarat & emberek hatalma & mindenki & népuralom \\
\hline $\begin{array}{l}\text { politikai szabadság- } \\
\text { jogok }\end{array}$ & szólásszabadság & $\begin{array}{l}\text { véleménynyilvánítás } \\
\text { szabadsága }\end{array}$ & sajtószabadság & \\
\hline nem létezik & $\begin{array}{l}\text { ilyen nincs Magyar- } \\
\text { országon }\end{array}$ & $\begin{array}{l}\text { ez nem az, ami meg- } \\
\text { valósult }\end{array}$ & utópia & \\
\hline $\begin{array}{l}\text { a demokrácia } \\
\text { múködtetése és } \\
\text { intézményei }\end{array}$ & választás, szavazás & $\begin{array}{l}\text { jog, jogállam, jogok } \\
\text { és kötelezettségek }\end{array}$ & politika, uralom & pártok, parlament \\
\hline függetlenség & szuverenitás & Magyarország & védelem, biztonság & önrendelkezés \\
\hline beleszólás & $\begin{array}{l}\text { beleszólás a dol- } \\
\text { gokba }\end{array}$ & $\begin{array}{l}\text { emberek véleménye } \\
\text { számít }\end{array}$ & $\begin{array}{l}\text { emberek egyetér- } \\
\text { tése }\end{array}$ & egymásra figyelés \\
\hline $\begin{array}{l}\text { materiális szempon- } \\
\text { tok }\end{array}$ & jólét & pénz & gazdaság & fejlődés \\
\hline érzelmi megközelítés & $\begin{array}{l}\text { pozitívumok (jó, } \\
\text { fontos stb.) }\end{array}$ & $\begin{array}{l}\text { negatívumok (ha- } \\
\text { zugság, hülyeség, } \\
\text { marhaság stb.) }\end{array}$ & & \\
\hline semmi, válaszhiány & semmi & nem tudja & nincs válasz & nem érdekli \\
\hline
\end{tabular}

*az egyes szavak rokonértelmü, hasonló jelentésü párjaival együtt.

Forrás: MTA TK V2018-3.

F2. táblázat.

Multinomiális regressziós modell a szóasszociációkra

\begin{tabular}{|c|c|c|c|c|c|c|c|c|}
\hline \multirow{2}{*}{\multicolumn{2}{|c|}{ ref=demokrácia nt, nv }} & \multirow{3}{*}{$\begin{array}{c}\text { B } \\
-1,024\end{array}$} & \multirow{3}{*}{$\begin{array}{l}\text { Std. } \\
\text { Hiba } \\
\\
272\end{array}$} & \multirow{3}{*}{$\begin{array}{l}\text { Wald } \\
14,119\end{array}$} & \multirow{3}{*}{$\begin{array}{l}\text { Szig. } \\
000 \\
\end{array}$} & \multirow{2}{*}{$\begin{array}{l}\text { Exp(B) } \\
\text { Alsó } \\
\text { határ }\end{array}$} & \multicolumn{2}{|c|}{$\begin{array}{l}\text { 95Konfidencia } \\
\text { intervallum }\end{array}$} \\
\hline & & & & & & & \multirow{2}{*}{$\begin{array}{l}\text { Felső } \\
\text { Határ }\end{array}$} & \\
\hline \multirow{12}{*}{ 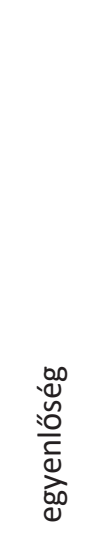 } & Intercept & & & & & & & \\
\hline & {$[$ nem $=0]$} & ,648 & ,238 & 7,415 & ,006 & 1,911 & 1,199 & 3,046 \\
\hline & {$[\mathrm{nem}=1]$} & $\mathrm{Ob}$ & & & & & & \\
\hline & [diploma $=, 00]$ & 972 & ,400 & 5,907 & ,015 & 2,644 & 1,207 & 5,792 \\
\hline & [diploma=1,00] & $\mathrm{Ob}$ & & & & & & \\
\hline & [bpvagysem=,00] & ,830 & ,323 & 6,619 & ,010 & 2,294 & 1,219 & 4,318 \\
\hline & [bpvagysem=1,00] & $\mathrm{Ob}$ & & & & & & \\
\hline & [demokráciapárti=,00] & 1,014 & 244 & 17,240 & , 000 & 2,758 & 1,708 & 4,452 \\
\hline & [demokráciapárti=1,00] & $\mathrm{Ob}$ & & & & & & \\
\hline & [korm_ellenz_ismeretlen=1,00] & ,776 & ,291 & 7,101 & 008 & 2,173 & 1,228 & 3,846 \\
\hline & [korm_ellenz_ismeretlen=2,00] &, 500 & ,296 & 2,867 & ,090 & 1,649 & 924 & 2,944 \\
\hline & [korm_ellenz_ismeretlen $=99,00]$ & $\mathrm{Ob}$ & & & & & & \\
\hline
\end{tabular}




\begin{tabular}{|c|c|c|c|c|c|c|c|c|}
\hline \multirow{2}{*}{\multicolumn{2}{|c|}{ ref=demokrácia nt, nv }} & \multirow{3}{*}{$\begin{array}{c}\text { B } \\
-1,537 \\
\end{array}$} & \multirow{3}{*}{$\begin{array}{l}\text { Std. } \\
\text { Hiba } \\
315\end{array}$} & \multirow{3}{*}{$\begin{array}{c}\text { Wald } \\
23,856 \\
\end{array}$} & \multirow{3}{*}{$\begin{array}{l}\text { Szig. } \\
, 000\end{array}$} & \multirow{3}{*}{$\begin{array}{l}\text { Exp(B) } \\
\text { Alsó } \\
\text { határ }\end{array}$} & \multicolumn{2}{|c|}{$\begin{array}{c}\text { 95Konfidencia } \\
\text { intervallum }\end{array}$} \\
\hline & & & & & & & Felső & \\
\hline \multirow{12}{*}{ 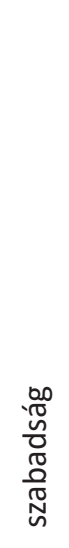 } & Intercept & & & & & & & \\
\hline & [nem=0] & ,368 & ,260 & 2,007 & 157 & 1,444 & ,868 & 2,402 \\
\hline & {$[$ nem $=1]$} & $\mathrm{Ob}$ & & & & & & \\
\hline & [diploma $=, 00]$ & 1,066 & ,420 & 6,437 & 011 & 2,903 & 1,274 & 6,613 \\
\hline & [diploma=1,00] & $\mathrm{Ob}$ & & & & & & \\
\hline & [bpvagysem $=, 00]$ & ,540 & ,355 & 2,318 & ,128 & 1,716 & ,856 & 3,439 \\
\hline & [bpvagysem $=1,00]$ & $\mathrm{Ob}$ & & & & & & \\
\hline & [demokráciapárti=,00] & 1,321 & ,272 & 23,627 & ,000 & 3,748 & 2,200 & 6,385 \\
\hline & [demokráciapárti=1,00] & Ob & & & & & & \\
\hline & [korm_ellenz_ismeretlen=1,00] &, 872 &, 326 & 7,129 & ,008 & 2,391 & 1,261 & 4,534 \\
\hline & [korm_ellenz_ismeretlen=2,00] &, 626 & ,333 & 3,539 &, 060 & 1,870 & ,974 & 3,589 \\
\hline & [korm_ellenz_ismeretlen $=99,00]$ & $\mathrm{Ob}$ & & & & & & \\
\hline \multirow{12}{*}{ 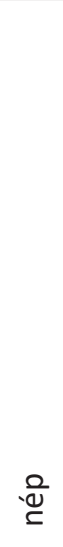 } & Intercept &,- 448 & ,259 & 2,991 & ,084 & & & \\
\hline & [nem $=0]$ &, 174 & ,237 &, 541 & ,462 & 1,190 & ,748 & 1,894 \\
\hline & {$[$ nem $=1]$} & $\mathrm{Ob}$ & & & & & & \\
\hline & [diploma $=, 00]$ & 1,289 & ,396 & 10,606 & 001 & 3,630 & 1,671 & 7,886 \\
\hline & [diploma=1,00] & $\mathrm{Ob}$ & & & & & & \\
\hline & [bpvagysem=,00] &,- 143 & ,356 & ,162 & ,687 & ,866 & ,431 & 1,741 \\
\hline & [bpvagysem $=1,00]$ & $\mathrm{Ob}$ & & & & & & \\
\hline & [demokráciapárti=,00] & ,615 & ,244 & 6,325 & ,012 & 1,849 & 1,145 & 2,986 \\
\hline & [demokráciapárti=1,00] & $\mathrm{Ob}$ & & & & & & \\
\hline & [korm_ellenz_ismeretlen=1,00] & ,778 & ,288 & 7,299 & ,007 & 2,178 & 1,238 & 3,829 \\
\hline & [korm_ellenz_ismeretlen=2,00] & ,362 & 299 & 1,461 & ,227 & 1,436 & ,799 & 2,582 \\
\hline & [korm_ellenz_ismeretlen $=99,00]$ & $\mathrm{Ob}$ & & & & & & \\
\hline \multirow{12}{*}{ 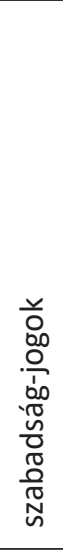 } & Intercept & $-1,179$ & ,292 & 16,250 & ,000 & & & \\
\hline & {$[$ nem $=0]$} & ,201 & ,249 &, 650 & ,420 & 1,222 &, 750 & 1,992 \\
\hline & {$[$ nem $=1]$} & $\mathrm{Ob}$ & & & & & & \\
\hline & [diploma $=, 00]$ & ,786 &, 420 & 3,500 & ,061 & 2,196 & ,963 & 5,004 \\
\hline & [diploma=1,00] & $\mathrm{Ob}$ & & & & & & \\
\hline & [bpvagysem=,00] &, 502 & ,345 & 2,110 & ,146 & 1,652 & ,839 & 3,251 \\
\hline & [bpvagysem=1,00] & $\mathrm{Ob}$ & & & & & & \\
\hline & [demokráciapárti=,00] & 1,382 & ,261 & 27,913 & ,000 & 3,981 & 2,385 & 6,647 \\
\hline & [demokráciapárti=1,00] & Ob & & & & & & \\
\hline & [korm_ellenz_ismeretlen=1,00] & ,697 & ,312 & 4,998 & ,025 & 2,007 & 1,090 & 3,696 \\
\hline & [korm_ellenz_ismeretlen=2,00] & ,599 & ,313 & 3,660 & 056 & 1,821 & ,985 & 3,363 \\
\hline & [korm_ellenz_ismeretlen=99,00] & $\mathrm{Ob}$ & & & & & & \\
\hline \multirow{12}{*}{ 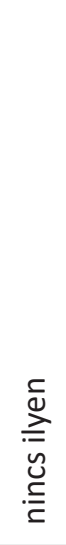 } & Intercept & $-1,235$ & ,363 & 11,551 & 001 & & & \\
\hline & [nem=0] & ,357 & ,337 & 1,124 & ,289 & 1,429 & ,739 & 2,765 \\
\hline & [nem=1] & $\mathrm{Ob}$ & & & & & & \\
\hline & [diploma $=, 00]$ &,- 642 & ,824 &, 608 & ,436 &, 526 & ,105 & 2,644 \\
\hline & [diploma=1,00] & $\mathrm{Ob}$ & & & & & & \\
\hline & [bpvagysem=,00] &,- 921 &, 630 & 2,137 & 144 & ,398 & 116 & 1,369 \\
\hline & [bpvagysem=1,00] & Ob & & & & & & \\
\hline & [demokráciapárti=,00] & ,364 & ,345 & 1,111 & ,292 & 1,439 & ,731 & 2,831 \\
\hline & [demokráciapárti=1,00] & Ob & & & & & & \\
\hline & [korm_ellenz_ismeretlen=1,00] &,- 883 &, 541 & 2,669 & ,102 & ,413 & ,143 & 1,193 \\
\hline & [korm_ellenz_ismeretlen=2,00] & ,843 & ,377 & 4,993 & 025 & 2,323 & 1,109 & 4,864 \\
\hline & [korm_ellenz_ismeretlen $=99,00]$ & $\mathrm{Ob}$ & & & & & & \\
\hline
\end{tabular}




\begin{tabular}{|c|c|c|c|c|c|c|c|c|}
\hline \multirow{2}{*}{\multicolumn{2}{|c|}{ ref=demokrácia nt, nv }} & \multirow{3}{*}{$\begin{array}{c}\text { B } \\
-1,151\end{array}$} & \multirow{3}{*}{$\begin{array}{r}\text { Std. } \\
\text { Hiba } \\
307\end{array}$} & \multirow{3}{*}{$\begin{array}{c}\text { Wald } \\
14,029\end{array}$} & \multirow{3}{*}{$\begin{array}{l}\text { Szig. } \\
, 000\end{array}$} & \multirow{2}{*}{$\begin{array}{c}\text { Exp(B) } \\
\text { Alsó } \\
\text { határ }\end{array}$} & \multicolumn{2}{|c|}{$\begin{array}{c}\text { 95Konfidencia } \\
\text { intervallum }\end{array}$} \\
\hline & & & & & & & & \\
\hline \multirow{12}{*}{ 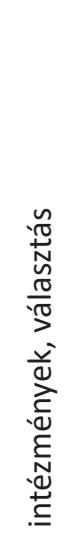 } & Intercept & & & & & & & \\
\hline & {$[$ nem $=0]$} & 088 & 270 & ,106 & ,745 & 1,092 & 643 & 1,852 \\
\hline & [nem $=1]$ & $\mathrm{Ob}$ & & & & & & \\
\hline & [diploma $=, 00]$ & 1,078 & ,434 & 6,187 & 013 & 2,940 & 1,257 & 6,877 \\
\hline & [diploma $=1,00]$ & $\mathrm{Ob}$ & & & & & & \\
\hline & [bpvagysem $=, 00]$ &,- 047 & 399 & 014 & ,906 & 954 & ,436 & 2,086 \\
\hline & [bpvagysem $=1,00]$ & Ob & & & & & & \\
\hline & [demokráciapárti=,00] & 1,175 & ,280 & 17,606 & ,000 & 3,239 & 1,871 & 5,609 \\
\hline & [demokráciapárti=1,00] & $\mathrm{Ob}$ & & & & & & \\
\hline & [korm_ellenz_ismeretlen $=1,00$ ] &, 554 & ,330 & 2,816 & 093 & 1,739 & 911 & 3,321 \\
\hline & [korm_ellenz_ismeretlen $=2,00]$ & 321 & 340 & ,892 & ,345 & 1,378 & ,708 & 2,681 \\
\hline & [korm_ellenz_ismeretlen $=99,00]$ & $\mathrm{Ob}$ & & & & & & \\
\hline \multirow{12}{*}{ 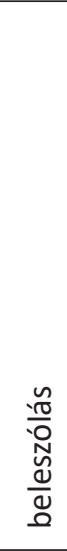 } & Intercept & $-2,587$ & ,468 & 30,559 & ,000 & & & \\
\hline & {$[\mathrm{nem}=0]$} &, 324 & ,335 & ,934 & ,334 & 1,382 & ,717 & 2,664 \\
\hline & {$[$ nem $=1]$} & ob & & & & & & \\
\hline & [diploma $=, 00]$ & 1,030 & ,502 & 4,214 & ,040 & 2,800 & 1,048 & 7,482 \\
\hline & [diploma=1,00] & ob & & & & & & \\
\hline & [bpvagysem $=, 00]$ & 195 & ,467 & 174 & 677 & 1,215 & ,486 & 3,036 \\
\hline & {$[$ bpvagysem $=1,00]$} & $\mathrm{Ob}$ & & & & & & \\
\hline & [demokráciapárti=,00] & 1,093 & ,347 & 9,915 & 002 & 2,982 & 1,511 & 5,887 \\
\hline & [demokráciapárti=1,00] & $\mathrm{Ob}$ & & & & & & \\
\hline & [korm_ellenz_ismeretlen $=1,00$ ] & 1,356 & ,469 & 8,359 & ,004 & 3,881 & 1,548 & 9,732 \\
\hline & [korm_ellenz_ismeretlen $=2,00$ ] & 1,109 & ,481 & 5,324 & 021 & 3,030 & 1,182 & 7,772 \\
\hline & [korm_ellenz_ismeretlen=99,00] & $\mathrm{Ob}$ & & & & & & \\
\hline \multirow{12}{*}{ בे } & Intercept & $-1,465$ & ,345 & 18,064 & ,000 & & & \\
\hline & {$[\mathrm{nem}=0]$} &, 445 & ,290 & 2,360 & 124 & 1,561 & ,884 & 2,754 \\
\hline & {$[\mathrm{nem}=1]$} & $\mathrm{Ob}$ & & & & & & \\
\hline & [diploma $=, 00]$ & 795 & ,470 & 2,862 & 091 & 2,215 & ,882 & 5,566 \\
\hline & [diploma=1,00] & $\mathrm{Ob}$ & & & & & & \\
\hline & [bpvagysem $=, 00]$ & ,008 & ,422 & ,000 & ,986 & 1,008 & ,441 & 2,303 \\
\hline & {$[$ bpvagysem $=1,00]$} & $\mathrm{ob}$ & & & & & & \\
\hline & [demokráciapárti=,00] &, 430 & ,296 & 2,115 & 146 & 1,538 & 861 & 2,746 \\
\hline & [demokráciapárti=1,00] & $\mathrm{Ob}$ & & & & & & \\
\hline & [korm_ellenz_ismeretlen $=1,00]$ & ,852 & ,371 & 5,286 & ,021 & 2,345 & 1,134 & 4,848 \\
\hline & [korm_ellenz_ismeretlen=2,00] & 857 & 370 & 5,349 & 021 & 2,356 & 1,140 & 4,870 \\
\hline & [korm_ellenz_ismeretlen $=99,00]$ & $\mathrm{ob}$ & & & & & & \\
\hline
\end{tabular}


F3. táblázat.

A demokráciával való elégedettség teljes, minden változót bevonó lineáris regressziós modellje és statisztikái

\begin{tabular}{|c|c|c|c|c|c|c|c|c|}
\hline \multirow{2}{*}{\multicolumn{2}{|c|}{$\begin{array}{l}\text { Model } \\
\text { B }\end{array}$}} & \multicolumn{2}{|c|}{$\begin{array}{c}\text { Nem standardizált } \\
\text { együttható }\end{array}$} & \multirow[t]{2}{*}{$\begin{array}{l}\text { Standardizált } \\
\text { együttható }\end{array}$} & \multirow[t]{2}{*}{$\mathrm{t}$} & \multirow{2}{*}{$\begin{array}{c}\text { Szig. } \\
\text { Tolerance }\end{array}$} & \multicolumn{2}{|c|}{$\begin{array}{l}\text { Kollinearitás } \\
\text { statisztikák }\end{array}$} \\
\hline & & Std. hiba & & & & & VIF & \\
\hline \multirow{14}{*}{1} & (Constant) & 791 & ,405 & & 1,955 & & & \\
\hline & demokrácia=egyenlőség & ,461 & ,308 & ,065 & 1,499 & 134 & ,382 & \\
\hline & demokrácia=szabadság & ,760 & ,332 & ,092 & 2,288 & 022 & ,455 & \\
\hline & demokrácia=nép & ,785 & ,310 & 108 & 2,535 & 011 & ,401 & \\
\hline & $\begin{array}{l}\text { demokrácia= szabadság- } \\
\text { jogok }\end{array}$ & 942 & ,322 & 120 & 2,921 & ,004 & ,432 & \\
\hline & nincs demokrácia=nincs & $-1,033$ & ,453 &,- 075 & $-2,284$ & 023 & 671 & \\
\hline & demokrácia= intézmény & ,049 & ,361 & ,005 & 137 & ,891 & ,498 & \\
\hline & demokrácia=beleszólás &,- 137 & ,417 &,- 011 &,- 327 & ,744 & ,625 & \\
\hline & $\begin{array}{l}\text { demokrácia=egyéb } \\
\text { (érzelem, materiális, } \\
\text { testvériség, függetlenség) }\end{array}$ & ,809 & 365 & 130 & 2,219 & 027 & 212 & \\
\hline & kor &,- 002 & ,005 &,- 009 &,- 347 & ,729 & 970 & \\
\hline & diploma & ,214 & 193 &, 030 & 1,111 & ,267 & 979 & \\
\hline & demokráciapárti vagy sem &,- 247 & ,157 &,- 044 & $-1,576$ & 116 & ,946 & \\
\hline & Fidesz-ellenzék & 1,650 & 196 & ,298 & 8,432 & ,000 & ,584 & \\
\hline & gazdasági elégedettség & ,441 & ,039 & ,398 & 11,381 & ,000 & ,594 & 1,684 \\
\hline
\end{tabular}

a. Függő változó: Mindent összevetve mennyire elégedett Magyarországon a demokrácia müködésével? Kérem, továbbra is 0-tól 10-ig terjedő skálát használjon! EGY VÁLASZ!

\begin{tabular}{|c|c|c|c|c|c|c|}
\hline & Modell & $R$ & $\mathrm{R}^{2}$ & Korrigált $\mathrm{R}^{2}$ & Standard hiba & \\
\hline & & ,652a & 0,425 & 0,415 & & \\
\hline $\begin{array}{l}\text { ANOVA } \\
\text { Modell }\end{array}$ & & Négyzetösszeg & & Átlag ${ }^{2}$ & F-próba & Szig. \\
\hline \multirow[t]{3}{*}{1} & Regressio & 2625,165 & 14 & 187,512 & 41,788 & ,000b \\
\hline & Residualis & 3545,606 & 790 & & & \\
\hline & Összesen & 6170,771 & & & & \\
\hline
\end{tabular}




\section{F1. ábra.}

A demokráciával való elégedettség átlagai és szórásai országonként, ESS1-ESS9 hullám (2002-2018)
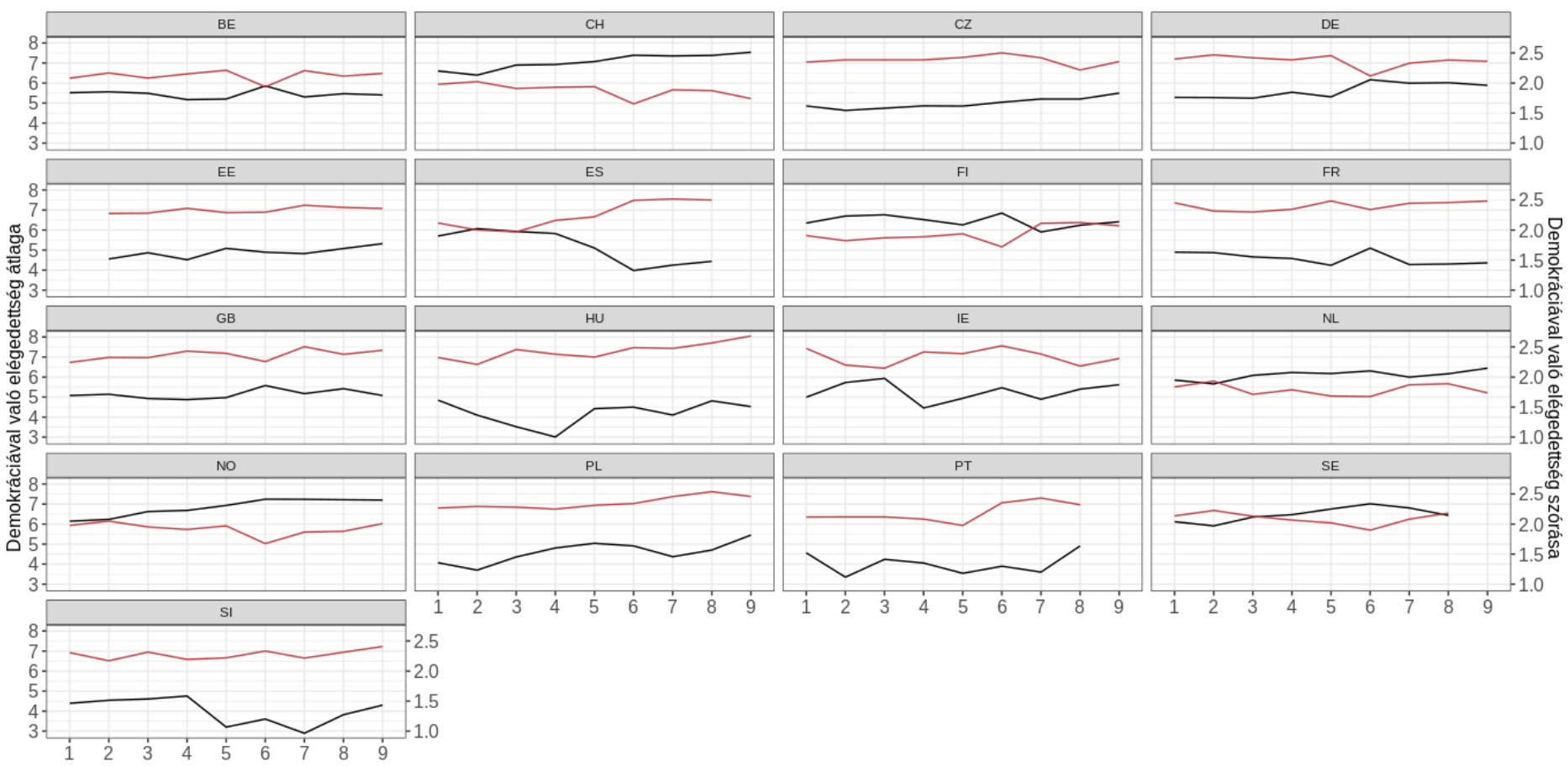

ESS Hullám

- Atlag — Szórás

Jelmagyarázat: Az ábrán azokat az országokat mutatjuk be, amelyek a legtöbb ESS hullámban részt vettek. Fekete vonallal jelöltük az elégedettségi átlagokat, amihez a skálabeosztás az ábra bal oldalán látható. Piros színnel pedig szórásokat ábrázoltuk, amihez a jobboldali skála tartozik. Forrás: ESS 01-09. 